\title{
PRELIMINARY THREE-DIMENSIONAL DISCRETE FRACTURE MODEL, TIVA CANYON TUFF, YUCCA MOUNTAIN AREA, NYE COUNTY, NEVADA
}

by Lawrence 0 . Anna

\section{U.S. GEOLOGICAL SURVEY}

Open-File Report 97-833

Prepared in cooperation with the

NEVADA OPERATIONS OFFICE,

U.S. DEPARTMENT OF ENERGY, under

Interagency Agreement DE-Al08-92NV10874 


\section{U.S. DEPARTMENT OF THE INTERIOR \\ BRUCE BABBITT, Secretary}

U.S. GEOLOGICAL SURVEY

Thomas J. Casadevall, Acting Director

The use of firm, trade, and brand names in this report is for identification purposes only and does not constitute endorsement by the U.S. Geological Survey.

For additional information write to:

Chief, Earth Science Investigations Program Yucca Mountain Project Branch U.S. Geological Survey Box 25046, Mail Stop 421

Denver Federal Center Denver, CO 80225-0046
Copies of this report can be purchased from:

U.S. Geological Survey Information Services

Box 25286

Federal Center

Denver, CO 80225 


\section{CONTENTS}

Abstract

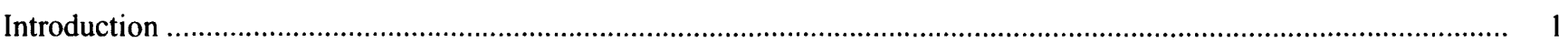

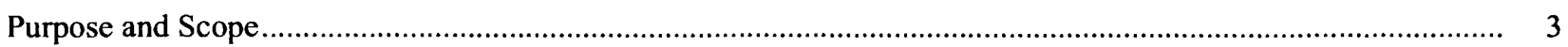

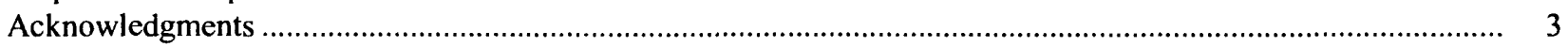

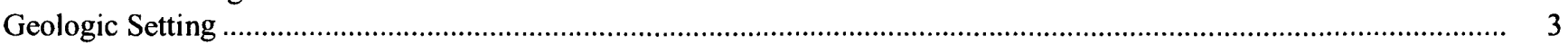

Structure

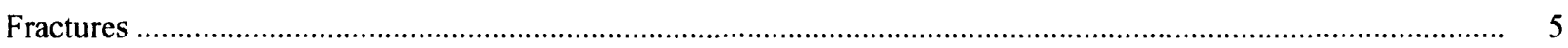

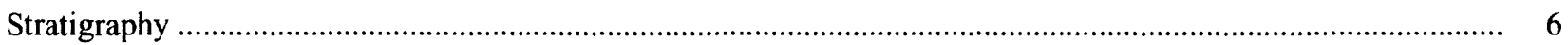

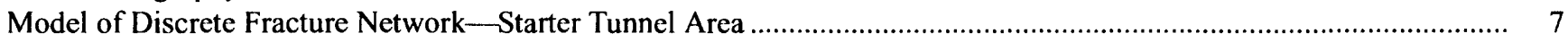

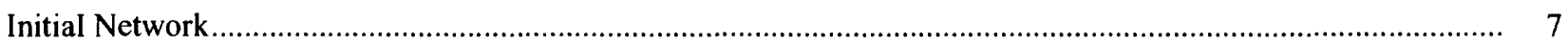

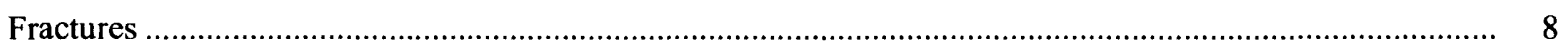

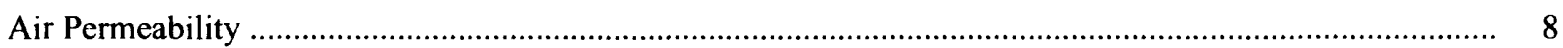

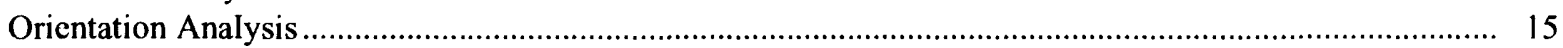

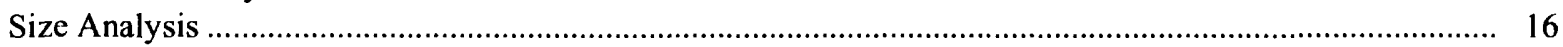

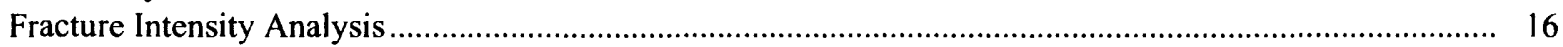

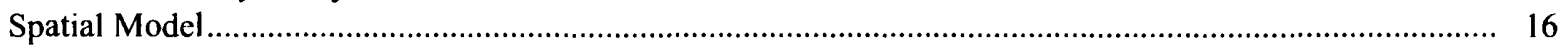

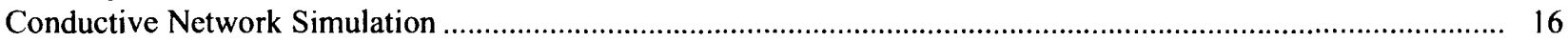

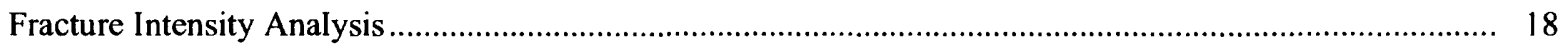

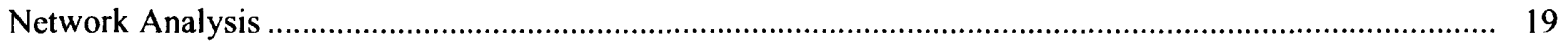

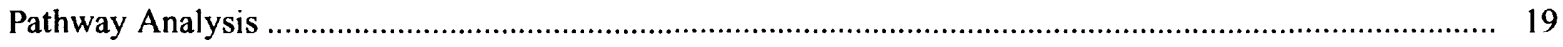

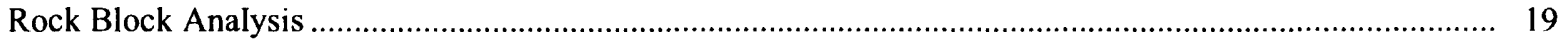

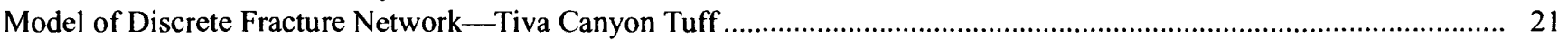

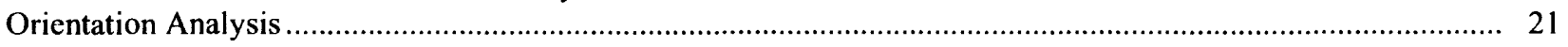

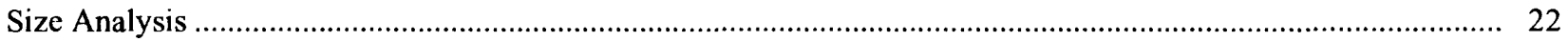

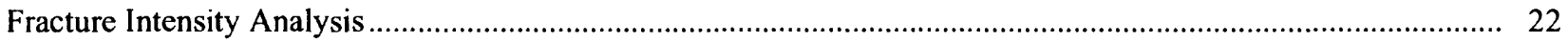

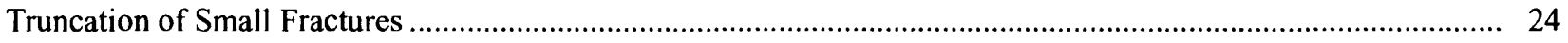

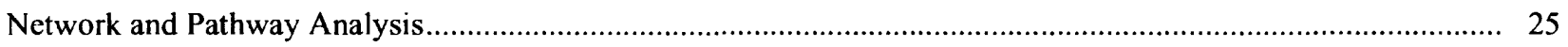

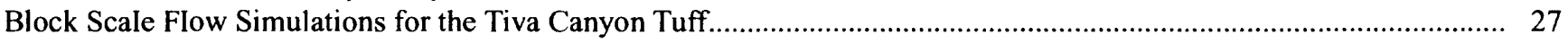

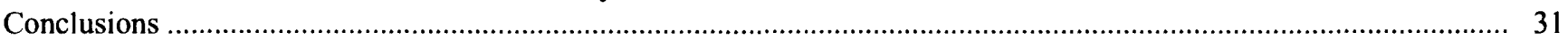

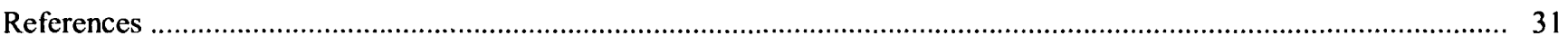

\section{Figures}

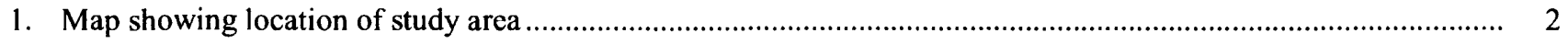

2. Map showing the starter tunnel and fracture generation areas ....................................................................

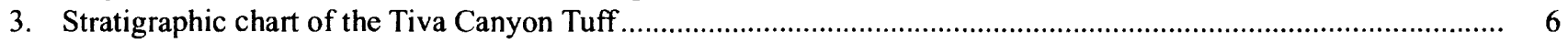

4. Equal area density-contour Schmidt pole and scatter plots for mapped fracture locations ................................. 9

5. Graphs showing mapped fracture trace lengths for combined sets, starter tunnel area ..................................... 15

6. Graph showing distribution of transmissivity values converted from air-permeability data from radial boreholes, alcove \#1, starter tunnel area ............................................................................................ 19

7. Equal-area Schmidt pole plots for fracture sets 1 through 4 and combined sets, starter tunnel area .................... 20

8. Schematic diagram showing network configuration and fracture intensities for each fracture subunit ................... 21

9. Equal-area Schmidt pole plots of mapped fractures for sets 1 through 3 and combined sets, Tiva Canyon Tuff ............................................................................................................................. 23

10. Graphs showing mapped fracture lengths for sets 1 through 3 and combined sets, Tiva Canyon Tuff ................... 24

11. Diagrams showing simulated and mapped fracture distributions in bench cut trace planes in the starter tunnel 


\section{Figures-Continued}

12. Diagram showing network and flow box configuration to determine directional permeability parallel to gradient.

13. Graphs showing permeability distribution for 10 realizations

\section{Tables}

1. Field data source

2. Input parameters for discrete fracture network model, starter tunnel area ................................................. 17

3. FracSize simulation results to determine fracture size from mapped trace lengths, starter tunnel area............... 17

4. Intensity and termination values from line and area surveys ................................................................. 17

5. Oxfilet simulation results for individual fractures, starter tunnel area ........................................................... 18

6. Results of network analysis, radial boreholes, alcove \#1, starter tunnel area .................................................. 19

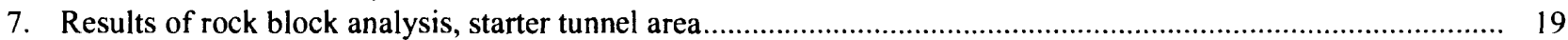

8. Fracture set parameters, Tiva Canyon Tuff, for all fracture subunits ........................................................... 22

9. Calculated initial (I) and connected (C) intensity values (P32) using the P2l and P10 calculation methods, Tiva Canyon Tuff

10. Mapped, simulated, and calculated fracture data................................................................................. 25

11. Initial (I) and connected (C) fracture intensities for each fracture subunit, Tiva Canyon Tuff .......................... 25

12. Network and pathway analysis for 150 -meter x 150-meter $x$ 60-meter flow box ............................................ 27

13. Network and pathway analysis for 200-meter $x$ 200-meter $x$ 60-meter flow box .......................................... 27

14. Bulk saturated directional permeabilities for 150 -meter $\times 150$-meter $\times 60$-meter flow box, Tiva Canyon Tuff

15. Bulk saturated directional permeabilities for 200-meter $\times 200$-meter $\times$ 60-meter flow box, Tiva Canyon Tuff

\section{CONVERSION FACTORS, VERTICAL DATUM, AND ABBREVIATIONS}

\begin{tabular}{rll}
\hline Multiply & By & To obtain \\
\hline micron $(\mu)$ & 0.00003937 & inch \\
meter $(\mathrm{m})$ & 3.281 & foot \\
kilometer $(\mathrm{km})$ & 0.6214 & mile \\
meter squared $\left(\mathrm{m}^{2}\right)$ & 10.76 & foot squared \\
square meter per cubic meter $\left(\mathrm{m}^{2} / \mathrm{m}^{3}\right)$ & 0.30 & square foot per cubic foot \\
cubic meter $\left(\mathrm{m}^{3}\right)$ & 35.31 & cubic foot \\
cubic meter per second $\left(\mathrm{m}^{3} / \mathrm{s}\right)$ & 35.31 & cubic foot per second
\end{tabular}

Sea level: In this report, "sea level" refers to the National Geodetic Vertical Datum of 1929 (NGVD of 1929) a geodetic datum derived from a general adjustment of the first-order level nets of both the United States and Canada, formerly called Sea Level Datum of 1929. 


\section{Preliminary Three-Dimensional Discrete Fracture Model, Tiva Canyon Tuff, Yucca Mountain Area, Nye County, Nevada}

\author{
By Lawrence O. Anna
}

\section{ABSTRACT}

A three-dimensional discrete fracture model was completed to investigate the potential effects of fractures on the flow of water at Yucca Mountain, Nye County, Nevada. A fracture network of the Exploratory Studies Facility starter tunnel area was simulated and calibrated with field data. Two modeled volumes were used to simulate threedimensional fracture networks of the Tiva Canyon Tuff. One volume had a width and length of 150 meters, and the other had a width and length of 200 meters; both volumes were 60 meters thick.

The analysis shows that the fracture system in the Exploratory Studies Facility starter tunnel area has numerous connected fractures that have relatively large permeabilities. However, pathway analysis between three radial boreholes indicated there were few pathways and little connection, which is consistent with results of cross-borehole pressure testing. Pathway analysis also showed that at the scales used there was only one pathway connecting one end of the flow box to the opposite end. The usual vertical pathway was along one large fracture, whereas in four horizontal directions the pathway was from multiple fracture connections. As a result, the fracture network can be considered sparse.

The fracture network was refined by eliminating nonconductive fractures determined from field-derived permeabilities. Small fractures were truncated from the simulated network without any effect on the overall connectivity. Fractures as long as 1.25 meters were eliminated (a large per- centage of the total number of fractures) from the network without altering the number of pathways.

Five directional permeabilities were computed for the 150- and 200-meter-scale flow box areas. Permeabilities for the 150-meter scale vary by almost two orders of magnitude, with the principal permeability direction being easterly. At the 200-meter scale, however, the flow box permeabilities only vary by a factor of four, with the principal permeability direction being vertical.

\section{INTRODUCTION}

Discrete fracture modeling is part of the site characterization for evaluating the flow of water and gas at Yucca Mountain, Nye County, Nevada, a potential high-level radioactive waste repository site (fig. 1). Fractures play an integral part in the hydraulics of flow and transport throughout the mountain (Montazer and Wilson, 1984). Historically, there is a tendency to model flow in fractured rock as an equivalent continuum because of the difficulty in evaluating severe heterogeneity. The equivalent continuum method replaces heterogeneous components with a single component having properties that mimic the response of the rock volume. If the rock volume is smaller than the scale of the conductive components, then the volume should show a spatial correlation. As a result, replacing the heterogeneous components with a single component is difficult. Different methods have been used to evaluate the heterogeneity and to attempt to evaluate and model discrete fracture networks (Andersson and Dverstorp, 1987; Cacas and others, 1990). Long and others (1982) developed criteria to determine when discrete fracture networks approach an equivalent continuum. Their analysis indicated that fractured rock approaches a con- 

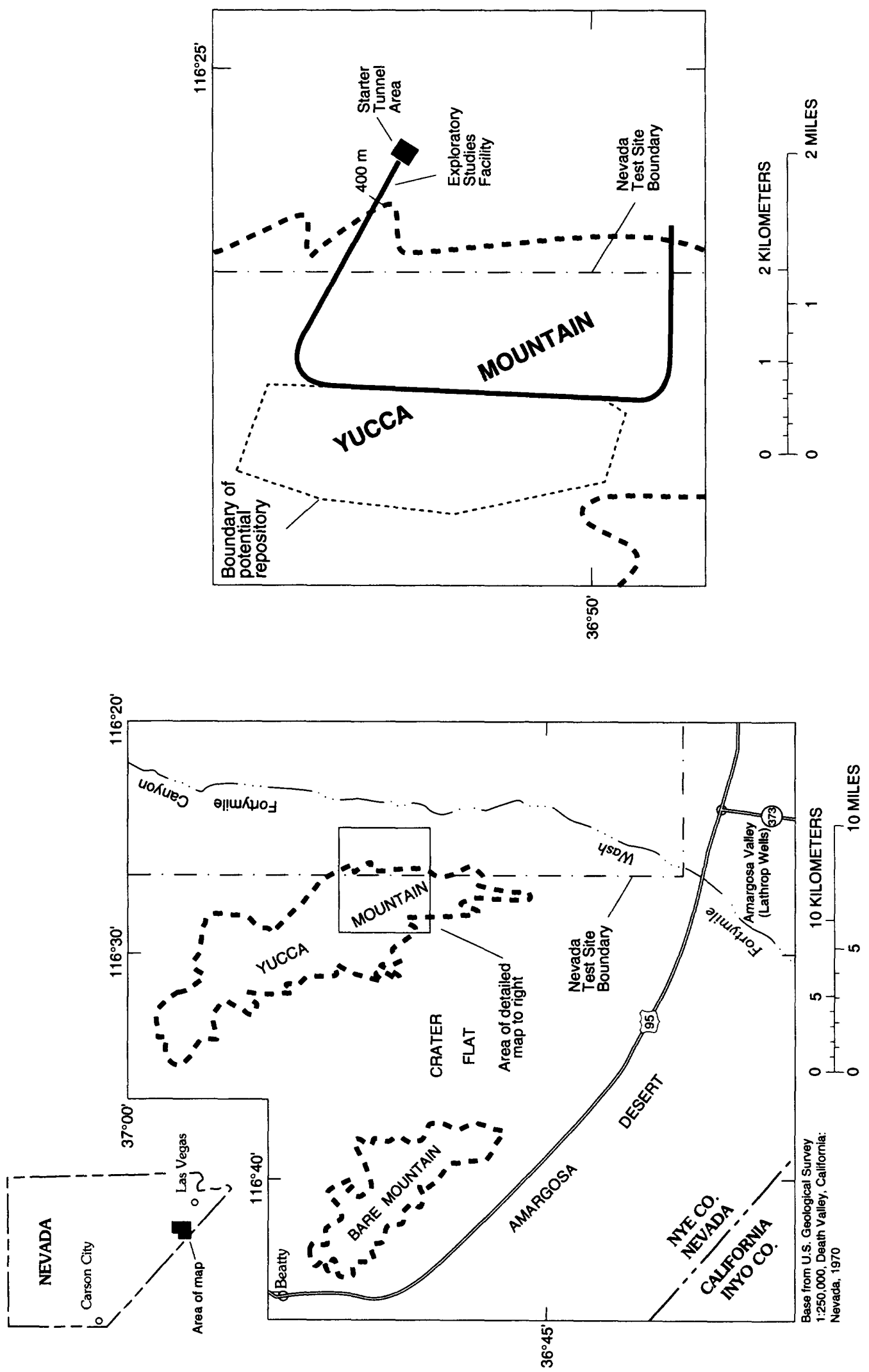

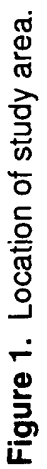


tinuum as (1) fracture density increases; (2) apertures are held constant rather than having a distribution; (3) fracture orientations become more variable rather than constant; and (4) rock volume increases.

Most of the problems of discrete fracture modeling depend on computational efficiency and on meaningful parameter input. It is extremely difficult to identify and analyze thousands of fractures and simulate them. As a result, this study has attempted to focus on the connectivity or conductivity of the network and not on the potential contribution of each fracture to the flow system. Fractures that are part of the flow system are identified as a function of the total volume, and fractures not part of the overall connectivity are eliminated. Connectivity or conductivity is related to fracture size, orientation, and intensity (Odling and Webman, 1990), although for any given, naturally occurring fracture network, fracture size is the most important variable (La Pointe and others, 1995). The larger the fracture, the more likely that it will connect with other large fractures. Thousands of randomly distributed small fractures do not have the same potential for connectivity as do several hundred very large fractures over large volumes. Eliminating the small, nonconnecting fractures is more efficient and provides better hydraulic matches with field data because most data collecting techniques truncate small fractures.

\section{Purpose and Scope}

The purpose of this report is to describe the construction of a three-dimensional fracture network, and the modeling of fluid flow through the network. As a result, the methodology developed in this preliminary report can be used to help evaluate other fractured volcanic rock units in the area, especially at the potential repository site. This report will focus on the following objectives: (1) Construct models of the discrete fracture networks (DFN) of the starter tunnel area (which includes part of the Tiva Canyon Tuff; fig. 2) and a more extensive area of the Tiva Canyon Tuff; (2) quantify the conductivity or connectivity of the network; and (3) determine bulk permeability in the direction of gradient for fracture networks at different scales. The modeling results will be used to: (1) help interpret testing in boreholes and in the Exploratory Studies Facility (ESF); and (2) help finalize input parameters and evaluate potential fast pathways for a model of the site as described in Wittwer and others (1993).

\section{Acknowledgments}

I am extremely grateful to Peter Wallmann and Paul La Pointe, Golder Associates, Redmond, Washington, who assisted in deciphering the FracMan modeling code (Dershowitz and others, 1994), and for their helpful discussions on modeling fracture networks. The U.S. Geological Survey (USGS), in cooperation with the U.S. Department of Energy conducted this study under interagency agreement DE-AI0892NV10874.

\section{GEOLOGIC SETTING}

The Yucca Mountain area is approximately $140 \mathrm{~km}$ northwest of Las Vegas, Nevada (fig. 1). The area consists of a thick sequence of carbonate and clastic rocks of Paleozoic age unconformably overlain by ash-fall and ash-flow tuffs of Miocene age. This volcanic sequence is about $1.5 \mathrm{~km}$ thick in the southern part of the area and thickens to about $1.8 \mathrm{~km}$ in the northern part. The source of the volcanic rock is the Timber Mountain-Oasis Valley caldera complex, several kilometers north of the Yucca Mountain area (Spengler and Fox, 1989).

The tuffs at Yucca Mountain are highly fractured because the area is located in complex tectonic and structural terrain. The terrain is characterized by locally restricted, basin-related extensional tectonics controlled by imbricate faults and a history of repeated movement over geologic time.

\section{Structure}

There are many complexities and enigmatic relations that prevent a clearly defined structural model of Yucca Mountain. Carr (1984) describes most of the features that may play an important part in the overall tectonism and structure of the area. The Yucca Mountain area consists of a series of block-faulted drapes of volcanic rocks of Miocene age. The faults are composed of three fundamental groups: One group propagated upward from underlying Paleozoic units, although little is known about this group's structural complexity; another is a surficial population that 


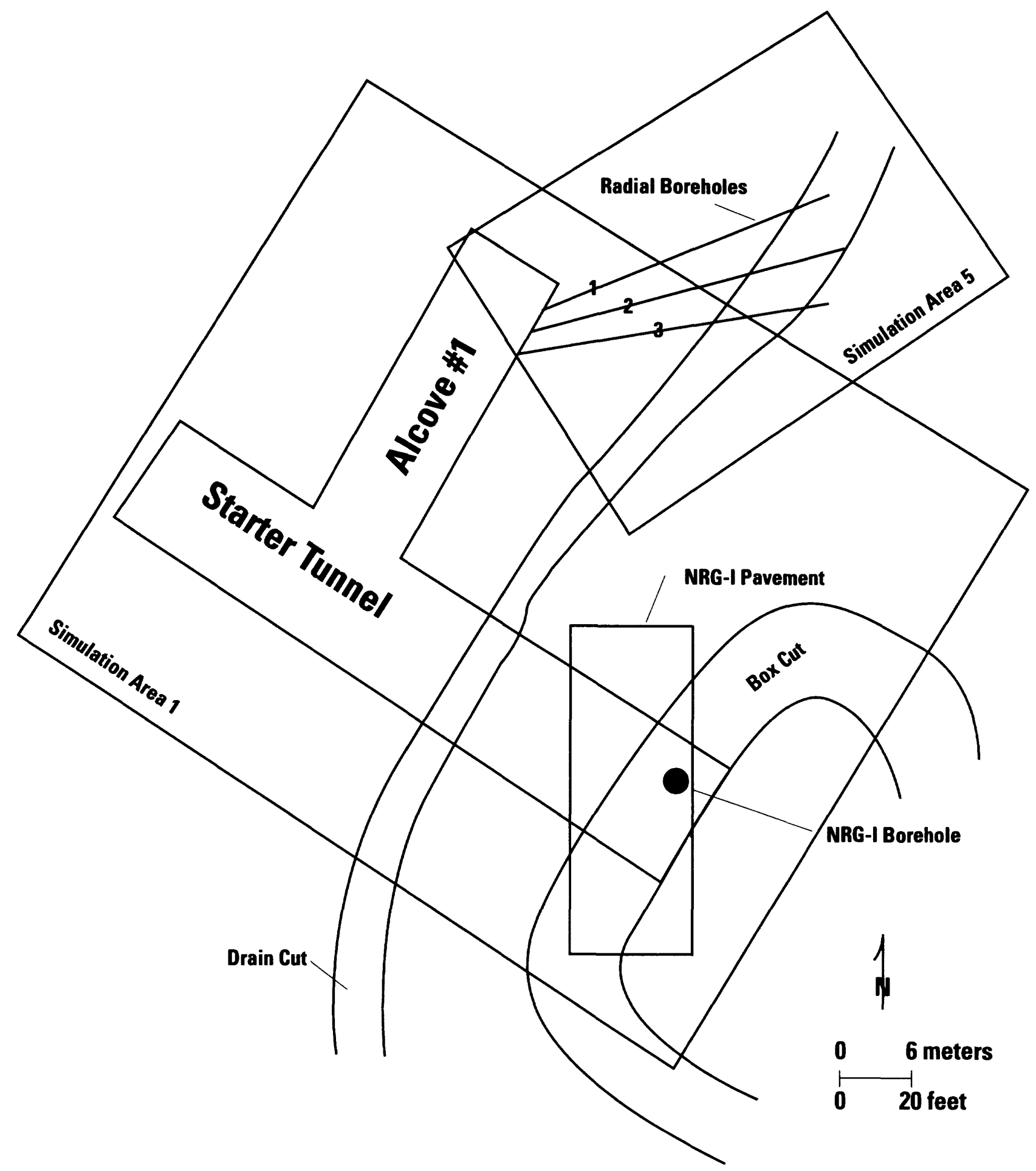

Figure 2. The starter tunnel and fracture generation areas. 
reflects failure and movement of the volcanic sequence; and finally a minor group of faults that occur along penecontemporaneous zones of weakness caused by cooling, degassing, and diagenetic alteration of the volcanic rocks.

In general, exposed rocks at Yucca Mountain form 5- to 15-degree east-dipping blocks separated by down-to-the-west normal faults with offsets of a few meters to several hundred meters (Frizzell and Shulters, 1990; Scott and Bonk, 1984). Extension faulting probably began prior to deposition of the Tiva Canyon Tuff (Scott, 1990) and continued throughout the deposition of the Tiva Canyon Tuff. Faults that trend north-south have dip-slip movement with possibly a minor component of strike-slip displacement (O'Neil and others, 1992). Northwest-southeast trending faults have right-lateral movement similar to the movement mapped in the Walker Lane structural zone (King, 1975, Wright, 1976). Northeast-southwest trending faults have left-lateral movement in the Spotted Range-Mine Mountain structural zone(Carr, 1984).

\section{Fractures}

Even though a large fracture data set has been collected at Yucca Mountain, there are still complexities and enigmatic relations that have not been resolved. Characteristics to distinguish cooling joints (Barton and Larsen, 1986) and tectonic fractures are not easily recognized. Conflicting termination relations also complicate fracture set chronology, origin, and stress history. Despite ambiguities, tectonic fractures at Yucca Mountain are thought to form in response to regional stresses (Throckmorton and Verbeek, 1995). As a result, fracture orientations probably do not change significantly in the vicinity of Yucca Mountain.

Chronological sequence of fracture sets is not clearly defined. It is unclear whether fracture sets formed separately under tension or as conjugate sets. However, based on detailed fracture mapping of pavements and uncleared areas, (D.S. Sweetkind, D.L. Barr, D.K. Polacsek, and L.O. Anna, U.S. Geological Survey, written commun., 1997) and Throckmorton and Verbeek (1995) indicate that despite ambiguities, a probable chronological sequence of fracture formation can be determined. The sequence starts with cooling joints that form contemporaneously with deposition and digenetic alteration of the ash-flow and ash-fall tuffs. Next are the tectonic fractures with north-south-trend- ing fractures forming first, followed by northwestsouthwest-trending fractures, then northeast-southwest trending fractures. A few east-west trending fractures are thought to be a result of unloading and formed last (Throckmorton and Verbeek, 1995). If these are unloading features, then they would not be present at depth.

Cooling joints have been mapped and described in the Yucca Mountain area by Barton and others (1993) and Throckmorton and Verbeek (1995), although their origin and range of characteristics is speculative. Mapping has been limited to parts of the total stratigraphic section. Cooling joints are not given special status as a distinct set because (1) the percentage of cooling joints to tectonic fractures is small; (2) distinction of cooling joints from tectonic fractures is not always definitive; and (3) orientations of cooling joints mapped by Throckmorton and Verbeek (1995) can be included in the tectonic sets. Mean orientations for the cooling joints (mapped by Throckmorton and Verbeek) are within 10 degrees of mean tectonic orientation for any particular set. This difference can be accounted for in the dispersion values calculated for each set.

Continuation of fractures between Tiva Canyon Tuff subunits is not generally known. Qualitative observation of the few contacts in outcrop shows some fractures extending between subunits of the Tiva Canyon Tuff. Sweetkind and others (written commun., 1997) indicate that in the moderately welded to nonwelded part of the hydrogeologic unit PTn (fig. 3), fractures are predominantly stratabound. They also state, however, that there probably is a significant number of fractures that connect the base of the welded Tiva Canyon columnar subzone to the upper part of the moderately welded vitric subzone.

Sweetkind and others (written commun., 1997) state that there are a number of controls that affect fracture characteristics. Some are related to stratigraphy and induration processes, as well as post-depositional tectonic processes. Variations in lithology, degrees of welding, devitrification, and lithophysae development within the Tiva Canyon Tuff control fracture properties, such as frequency and length.

Numerous faults in the area have been mapped (Scott and Bonk, 1984) and are shown either as potential fast pathways or as barriers to water and gas flow (Montazer and Wilson, 1984). Because hydraulic properties of the faults in the area have not been determined, and the relation between faults and fractures has not yet been determined, this preliminary study does not include faults as part of the connectivity of the system. 


\begin{tabular}{|c|c|c|c|c|c|}
\hline \multicolumn{4}{|c|}{ Lithologic units } & $\begin{array}{l}\text { Fracture } \\
\text { subunits }\end{array}$ & $\begin{array}{c}\text { Hydrogeologic } \\
\text { units }\end{array}$ \\
\hline \multirow{9}{*}{$\begin{array}{l}\text { Tiva Canyon } \\
\text { Tuff } \\
\text { (12.7 million } \\
\text { years old) }\end{array}$} & \multirow{3}{*}{$\begin{array}{l}\text { Crystal-rich } \\
\text { member }\end{array}$} & Vitric & $\begin{array}{c}\text { Nonwelded, } \\
\text { moderately } \\
\text { welded, densely } \\
\text { welded }\end{array}$ & \multirow[t]{2}{*}{ Upper } & \multirow[t]{8}{*}{ TCw } \\
\hline & & $\begin{array}{c}\text { Non- } \\
\text { lithophysal }\end{array}$ & & & \\
\hline & & Lithophysal & & \multirow{5}{*}{ Middle } & \\
\hline & \multirow{6}{*}{$\begin{array}{l}\text { Crystal-poor } \\
\text { member }\end{array}$} & $\begin{array}{c}\text { Upper } \\
\text { lithophysal }\end{array}$ & & & \\
\hline & & $\begin{array}{l}\text { Middle non- } \\
\text { lithophysal }\end{array}$ & & & \\
\hline & & $\begin{array}{l}\text { Lower } \\
\text { lithophysal }\end{array}$ & Hackly-fractured & & \\
\hline & & \multirow{2}{*}{$\begin{array}{l}\text { Lower non- } \\
\text { lithophysal }\end{array}$} & Hackly & & \\
\hline & & & Columnar & Lower & \\
\hline & & Vitric & $\begin{array}{l}\text { Moderately } \\
\text { welded, } \\
\text { nonwelded }\end{array}$ & & PTn \\
\hline
\end{tabular}

Figure 3. Stratigraphic chart of the Tiva Canyon Tuff. Modified from Buesch and others (1996), Scott and Bonk (1984).

\section{Stratigraphy}

Stratigraphy of the Tiva Canyon Tuff of Miocene age at Yucca Mountain is relatively simple and uncomplicated (fig. 3). The vertical sequence is probably the result of one ash-flow cycle separated by unconformities at the top and bottom. A simplified cycle consists of an asymmetric bulk density profile of non- to moderately welded tuff at the top and bottom with welded to densely welded tuff in the middle.

A basic depositional model for ash-flow tuffs (Riehle, 1973, and Riehle and others, 1995) is used in this study. The depositional model is used to add confidence to the vertical subdivisions that were determined as part of the flow model volume. Computed compaction, density, and porosity profiles indicate the tuffs are asymmetric, with a gradual slope in the upper part and a fairly sharp base. Local variations from this general profile may occur because of temperature or chemistry anomalies. The middle parts are welded to densely welded and have porosities of 0 to 5 percent. The upper and lower parts are non- to moderately welded, and have porosities as high as 45 percent. Riehle and others (1995) described the Matahina Ignimbrite, New

Zealand, which has similar characteristics to the Tiva Canyon Tuff. Based on density profiles, the ignimbrite was divided into three members. The basal member is thin and devitrified including a vitrophyre layer. The middle member is a thick devitrified section with the upper part consisting of a vapor-phase crystallization zone, and the upper member is a thin vapor-phase crystallization layer. The Tiva Canyon Tuff has a similar profile (Buesch and others, 1996). 
The Tiva Canyon Tuff was divided into several informal stratigraphic units based on internal texture, percent of phenocrysts, presence or absence of lithophysae, and degree of welding (Buesch and others, 1996). Thicknesses range from zero where the unit has been completely eroded to about $140 \mathrm{~m}$ (Scott and Bonk, 1984) along ridge tops. A complete section of the Tiva Canyon Tuff rarely is exposed in outcrop or in boreholes.

\section{MODEL OF DISCRETE FRACTURE NETWORK-STARTER TUNNEL AREA}

The construction of the DFN is done in two parts, first, the initial network and then the conductive network. The initial network is constructed and calibrated to mapped data. The conductive network is then constructed by determining the frequency of conductive fractures, converting that frequency into new intensity parameters, and constructing a new network.

\section{Initial Network}

This study uses the forward modeling approach of FracMan (Dershowitz and others, 1994) to develop a simulated 3-D discrete fracture network. This approach provides alternative probabilistic descriptions of fracture parameters by comparing multiple simulations with field measurements. By simulating field measurements from assumed parameters, forward modeling can account for error, biases, and uncertainties resulting from data-collection procedures. Forward modeling assumes that simulated parameters could account for field observations. Therefore, different conceptual models are possible, depending on how valid or appropriate they are compared with field observations.

Field data were collected from outcrop line and area surveys, boreholes, and from borehole packer tests (table 1). All data that were used in the interpretive part of this report were collected, reviewed, and verified under a quality assurance program ( $Q$ status). Some data did not meet the quality assurance requirements (non-Q) and were only used to corroborate other data

Table 1. Field data source

[NA, not available; $Q$, qualified; *, non-qualified data were used in corroborating, not direct, calculations]

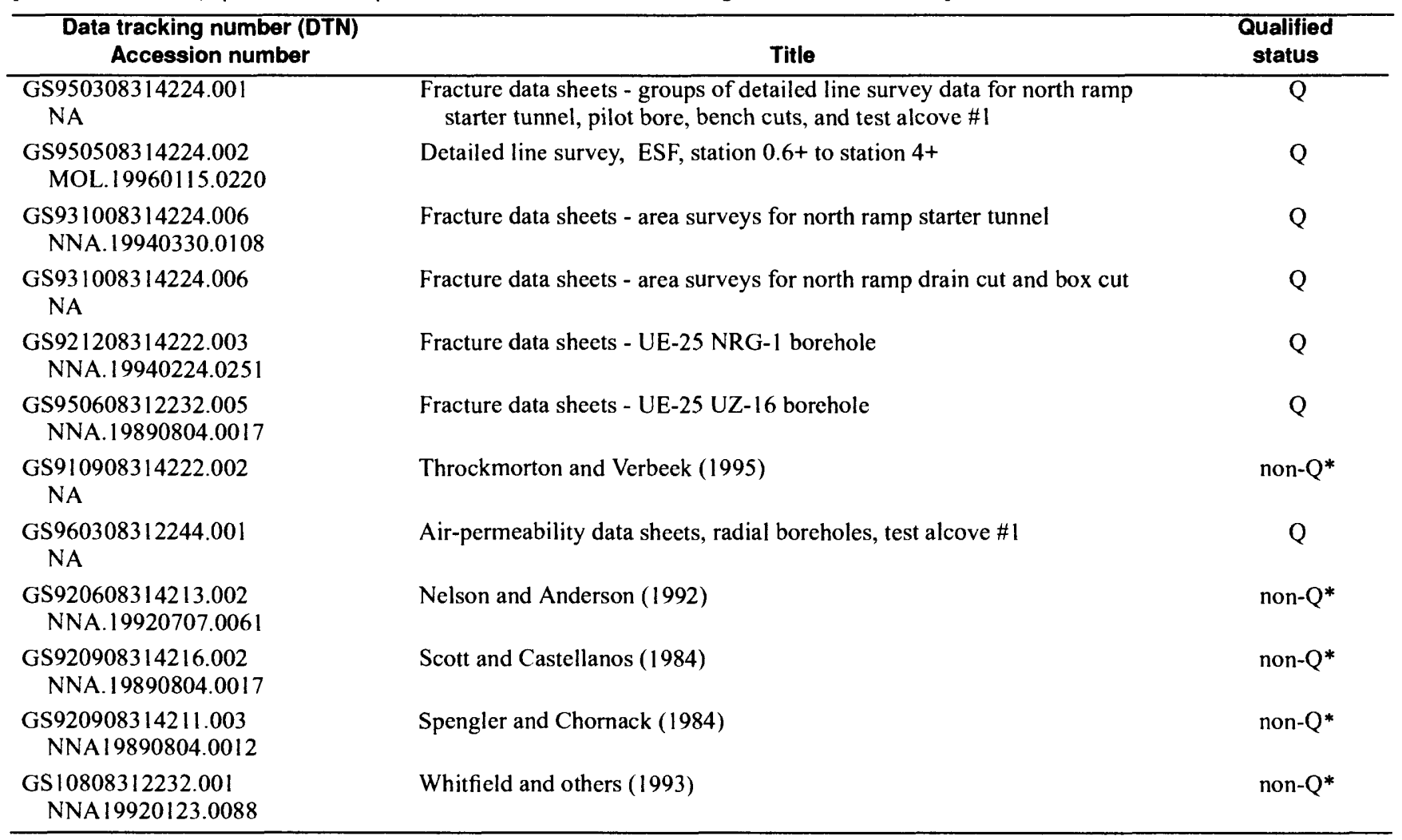


for this report. Field data analysis consisted of developing distributions of fracture length, orientation, and transmissivity. Fracture properties were derived by using modules in FracMan to convert fracture length to fracture size or radius, convert raw orientation data into distinct orientation distributions or sets, and convert packer-test derived transmissivities into a conductive fracture intensity or frequency and transmissivity distribution. Once the field data were converted into fracture properties that could be used as simulation input, fracture networks were simulated using stochastic methods. The simulated networks were calibrated by comparing mean intensities to mapped intensities. The simulated network could then be analyzed for its connectivity, in addition to the solution of flow equations.

\section{Fractures}

Field data were collected by different investigators and used to create a discrete fracture network. Data include fracture frequency, orientation, length, and airpermeability values. Primary sources for fracture data were detailed line surveys from the starter tunnel, and debris-cleared areas around the starter tunnel (fig. 2). Only fracture frequency (number/length) data were used from boreholes for this study, and used only in corroboration with other data sources (table 1). Line surveys were used to map fracture frequency, orientation, and length. Line surveys were located in the north portal starter tunnel ( $60 \mathrm{~m}$ long, $9.15 \mathrm{~m}$ diameter), in alcove \#1 (30 m long, $8.5 \mathrm{~m}$ diameter, nearly perpendicular to the starter tunnel), and in the first $400 \mathrm{~m}$ of the ESF, (7.6-m-diameter tunnel excavated with a boring machine attached and parallel to the starter tunnel, fig. 2). Area and line surveys were located in box and drain cuts at the entrance to the starter tunnel. Area surveys of selected outcrops of the Tiva Canyon Tuff in the Yucca Mountain area are presented by Throckmorton and Verbeek (1995). Their surveys were not used as direct input, but were used to help determine termination percentages and a chronological sequence of fracture generation.

Uncorrelated orientation data from line and area mapping are presented in figure 4. Mapped orientations were plotted on equal-area density-contour Schmidt pole and scatter plots. The mapped fractures exhibit multimodal concentrations with several distinct sets that may be modeled using a Fisher distribution (Fisher, 1953). Terzaghi corrections (Terzaghi, 1965) were applied to all line surveys before being used for flow modeling.
Uncorrected length data from line and area surveys are presented in figure 5 for all mapped fractures and for individual sets. Uncorrected field measurements of fracture lengths can have biases (Hudson and Priest, 1983; LaPointe and Hudson, 1985). For example, censoring can occur when one or both ends of the fracture trace extend beyond the boundary of observation. Also, lengths measured in the tunnel may be minimal as a result of the finite sampling area. Truncation can occur when a fracture trace is smaller than some artificial cutoff length. In addition, scan lines will tend to sample fractures that are longer rather than shorter. In general, mean fracture lengths that are not corrected tend to underestimate the true mean fracture size. These types of bias can be corrected when fracture length is converted to an equivalent fracture radius using the FracSys module in FracMan (Dershowitz and others, 1994).

\section{Air Permeability}

The USGS has developed methods and equipment to provide estimates of in-situ gas permeability values in fractured rock (LeCain, 1995, LeCain, 1997). For the starter tunnel area, air-permeability testing data for three subhorizontal, triangularly positioned, boreholes radiating from alcove \#1 (fig. 2) were used to determine a transmissivity distribution and frequency of conductive fractures. Each borehole was tested using approximately $1.3-\mathrm{m}$-long packer intervals. The packed off interval was injected with air to a steadystate flow condition using different flow rates. Injection was stopped, and a recovery curve was evaluated (G.D. LeCain, U.S. Geological Survey, written commun., 1995). Converted transmissivity distributions for the boreholes in alcove \#1 is shown in figure 6. From visual inspection, the histogram shows roughly a bimodal lognormal distribution with values that range from $3.36 \times 10^{-13}$ to $1.53 \times 10^{-09} \mathrm{~m}^{3}$.

Studies of core samples from the three boreholes indicated that the tested rock is a crystal-rich, lithophysal subunit of the Tiva Canyon Tuff. This subunit is welded to densely welded indicating that matrix permeability is probably too low to be a factor in the permeability calculations.

Air-permeability values collected from the three boreholes in alcove \#1 (and converted to transmissivity values) have unavoidable uncertainties. For example, only parts of the boreholes could be tested because in some parts packers would not seat properly because of borehole washouts. Therefore, there was only a limited 


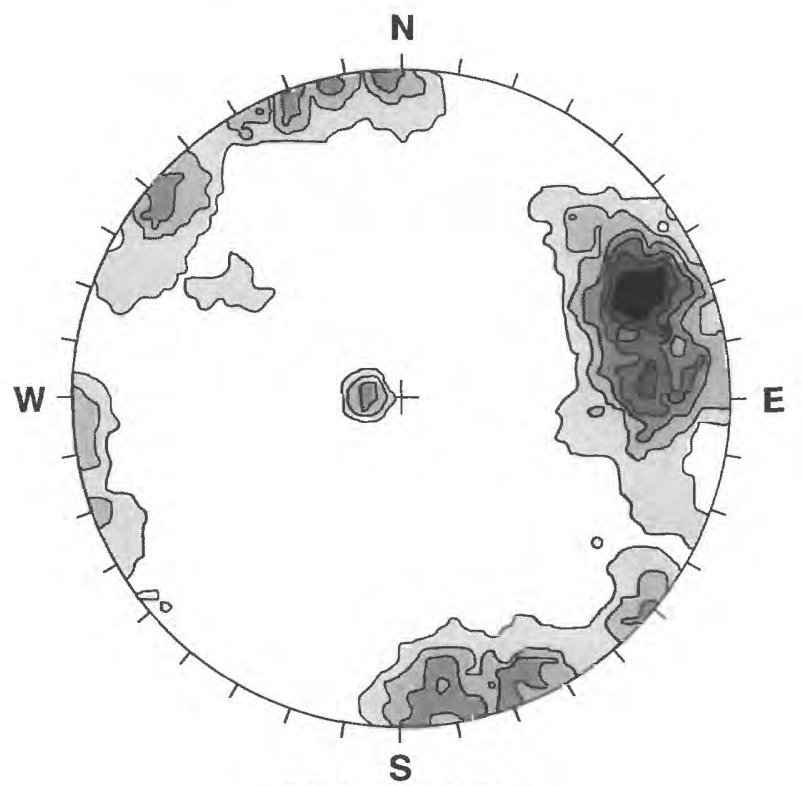

POLES TO PLANES

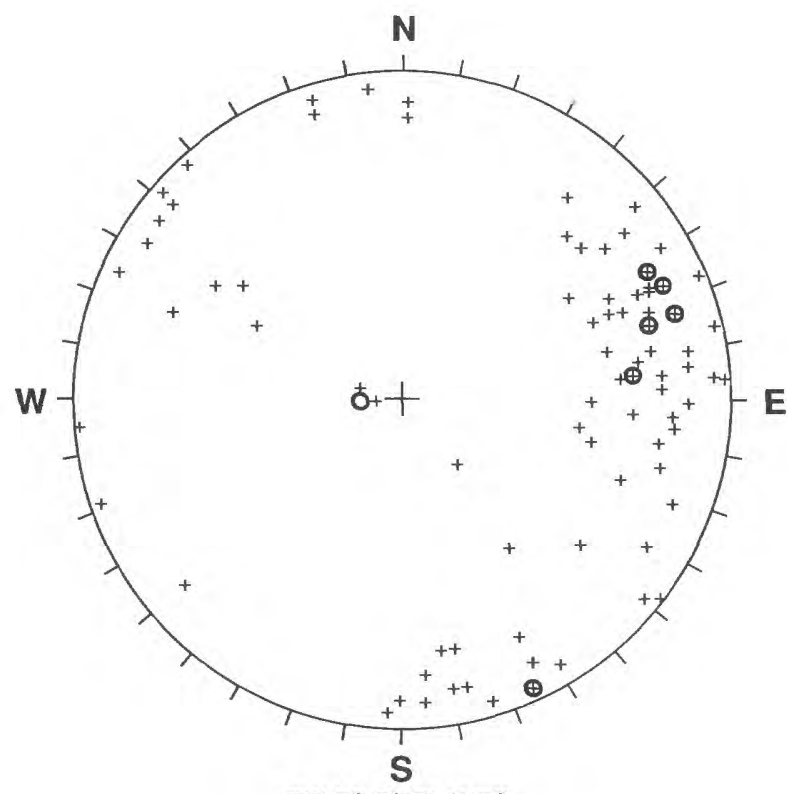

POLES TO PLANES
CONTOUR PLOT

SCHMIDT POLE CONCENTRATIONS

$\%$ of total per

$1.0 \%$ area

$<0$

$<1.67 \%$

$<3.33 \%$

$<5 \%$

$<6.67 \%$

$<8.33 \%$

$<10 \%$

$<$ more

EQUAL ANGLE

LOWER HEMISPHERE

96 POLES

96 ENTRIES

NO BIAS

CORRECTION

\section{SCATTER PLOT \\ NUMBER OF \\ POLES \\ +1 pole \\ $\oplus 2$ poles \\ - 3 poles}

EQUAL ANGLE LOWER HEMISPHERE

96 POLES

96 ENTRIES

Figure 4a. Equal-area density-contour Schmidt pole and scatter plots for mapped fracture locations. A. Left wall. B. Right wall. C. Box cut. D. Drain cut. E. Alcove \#1. F. NRG-1 pavement. 


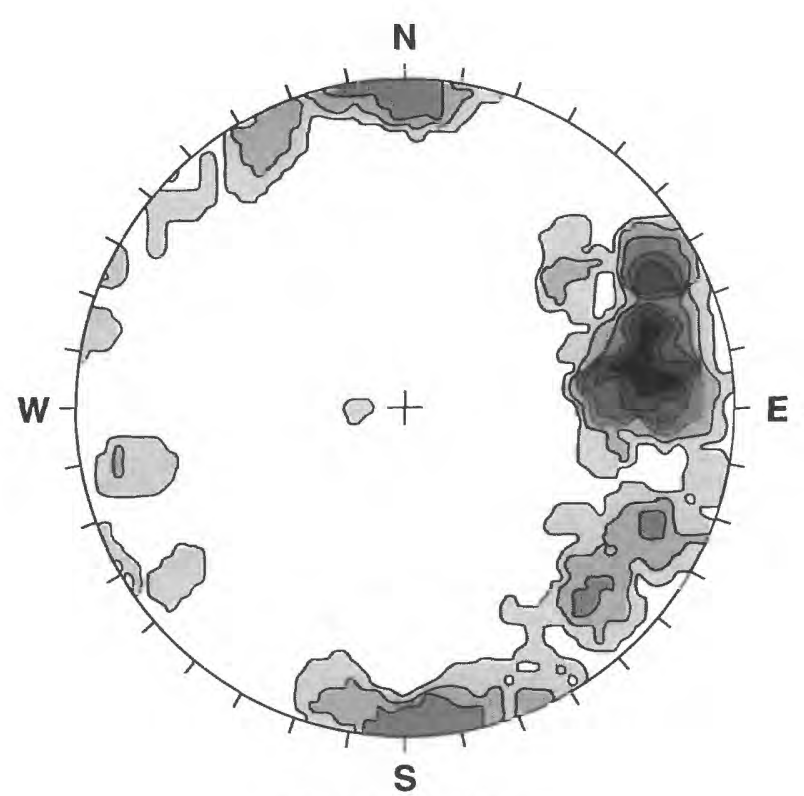

POLES TO PLANES

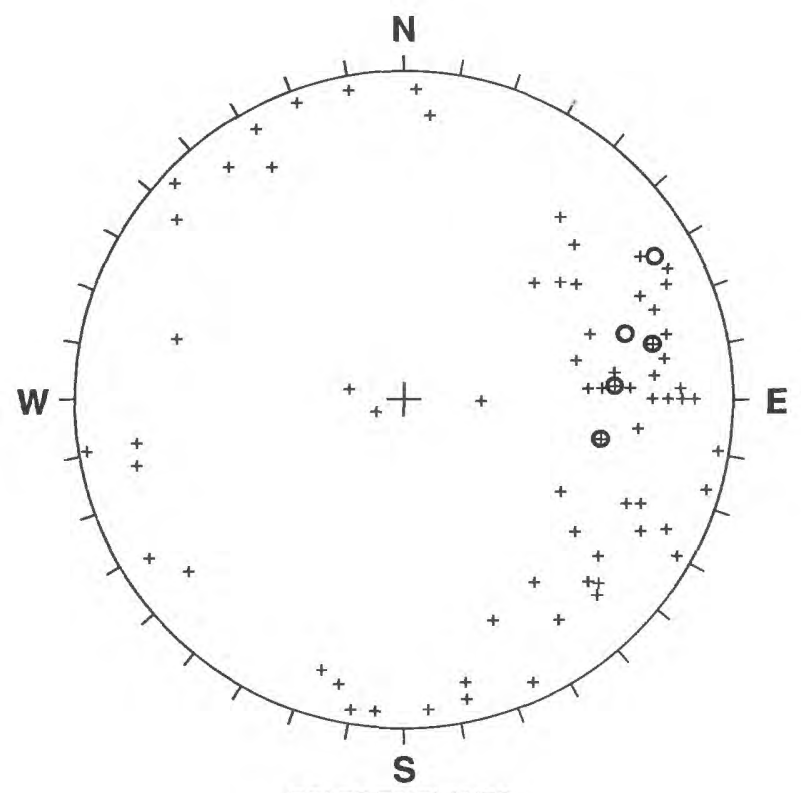

POLES TO PLANES
CONTOUR PLOT

SCHMIDT POLE CONCENTRATIONS

$\%$ of total per

$1.0 \%$ area

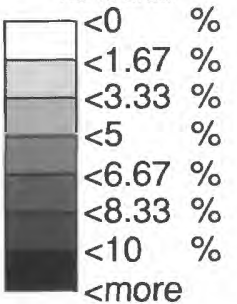

EQUAL ANGLE LOWER HEMISPHERE

80 POLES

80 ENTRIES

NO BIAS

CORRECTION

\section{SCATTER PLOT NUMBER OF POLES \\ +1 pole \\ $\oplus 2$ poles \\ - 3 poles}

EQUAL ANGLE LOWER HEMISPHERE 80 POLES 80 ENTRIES

Figure 4b. Equal-area density-contour Schmidt pole and scatter plots for mapped fracture locations. A. Left wall. B. Right wall. C. Box cut. D. Drain cut. E. Alcove \#1. F. NRG-1 pavement-Continued. 


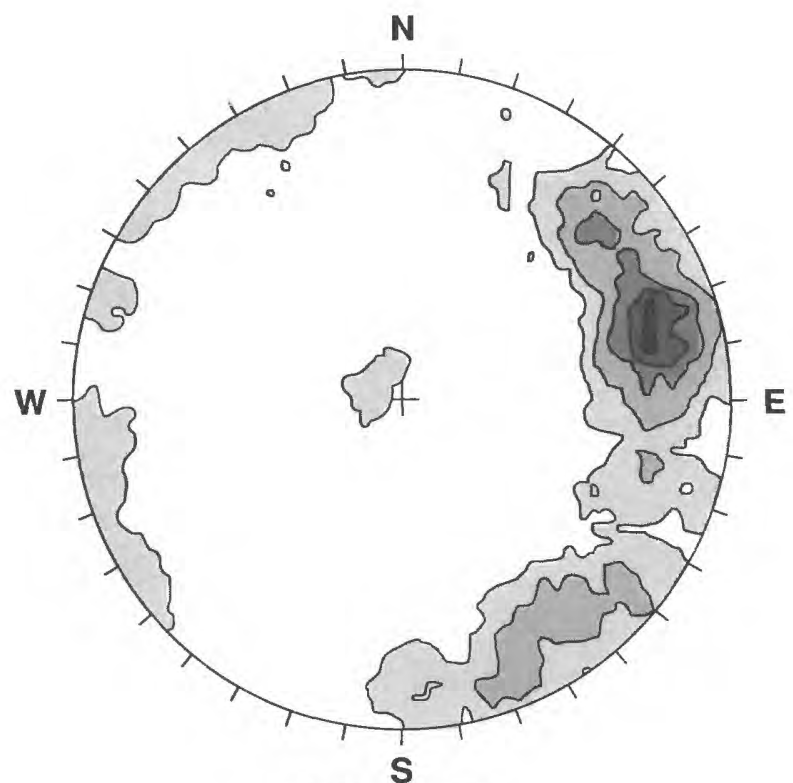

POLES TO PLANES

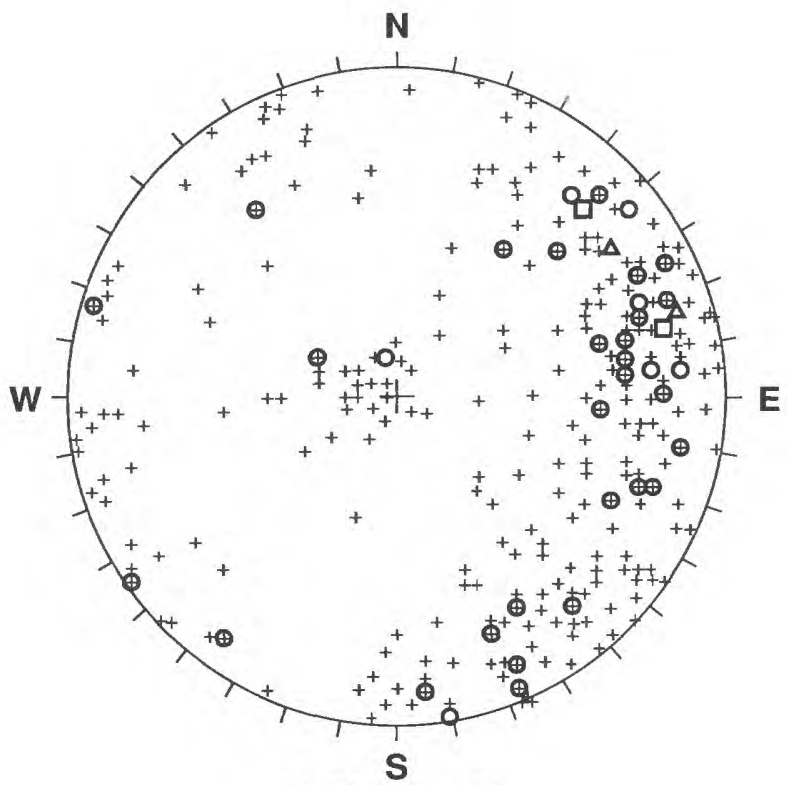

POLES TO PLANES
CONTOUR PLOT

SCHMIDT POLE

CONCENTRATIONS

$\%$ of total per

$1.0 \%$ area

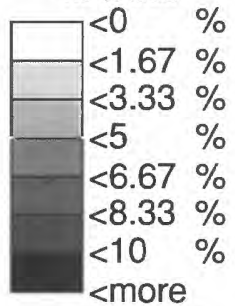

EQUAL ANGLE LOWER HEMISPHERE

330 POLES 330 ENTRIES

NO BIAS

CORRECTION

\section{SCATTER PLOT \\ NUMBER OF
POLES \\ +1 pole \\ $\oplus 2$ poles \\ - 3 poles \\ 口 4 poles \\ $\triangle 5$ poles}

\section{EQUAL ANGLE}

LOWER HEMISPHERE

330 POLES

330 ENTRIES

Figure 4c. Equal-area density-contour Schmidt pole and scatter plots for mapped fracture locations. A. Left wall. B. Right wall. C. Box cut. D. Drain cut. E. Alcove \#1. F. NRG-1 pavement-Continued. 

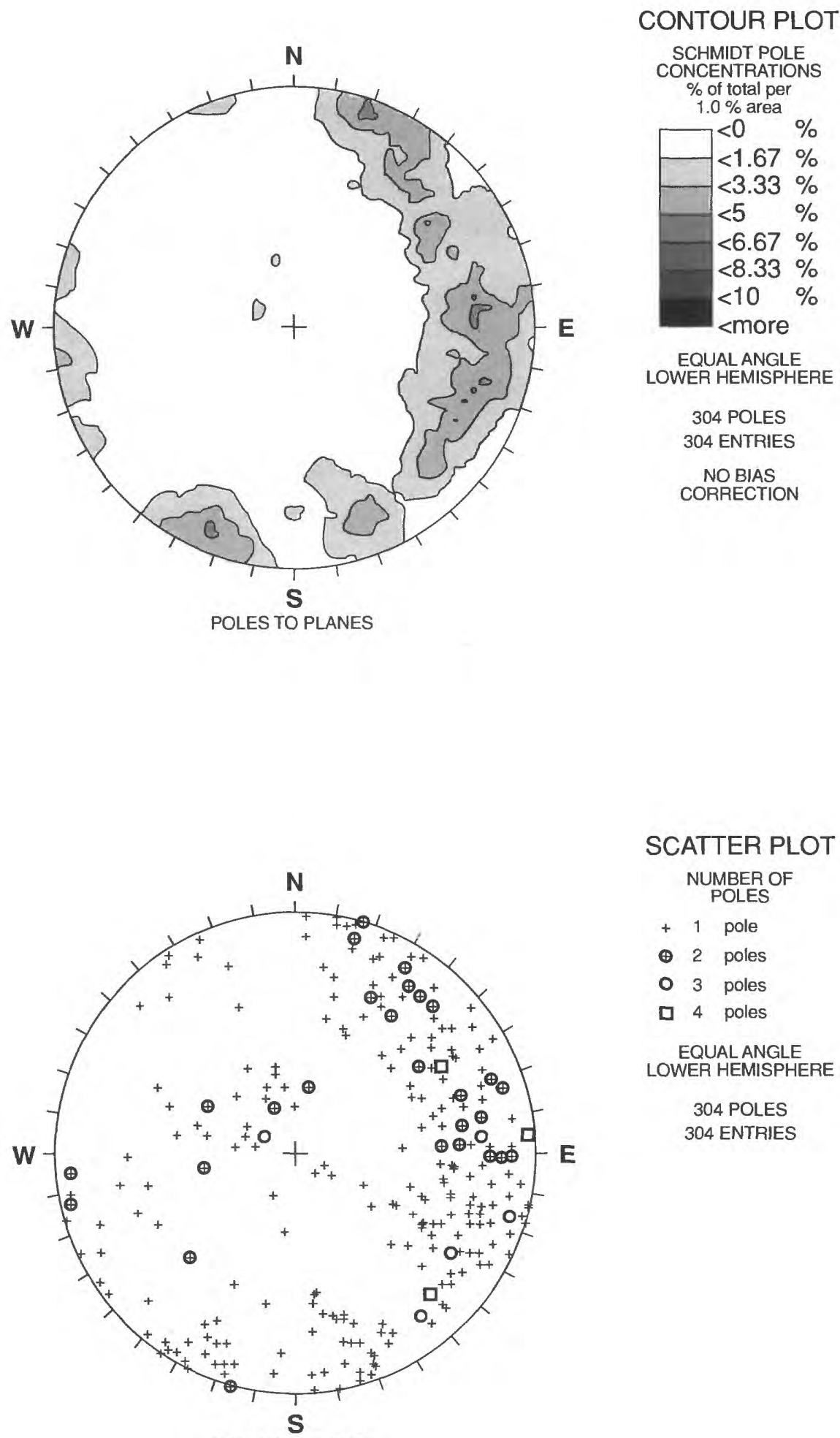
SCATTER PLOT NUMBER OF
POLES
+1 pole
$\oplus 2$ poles
- 3 poles
ㅁ 4 poles

EQUAL ANGLE LOWER HEMISPHERE

304 POLES 304 ENTRIES

POLES TO PLANES

Figure 4d. Equal-area density-contour Schmidt pole and scatter plots for mapped fracture locations. A. Left wall. B. Right wall. C. Box cut. D. Drain cut. E. Alcove \#1. F. NRG-1 pavement-Continued. 


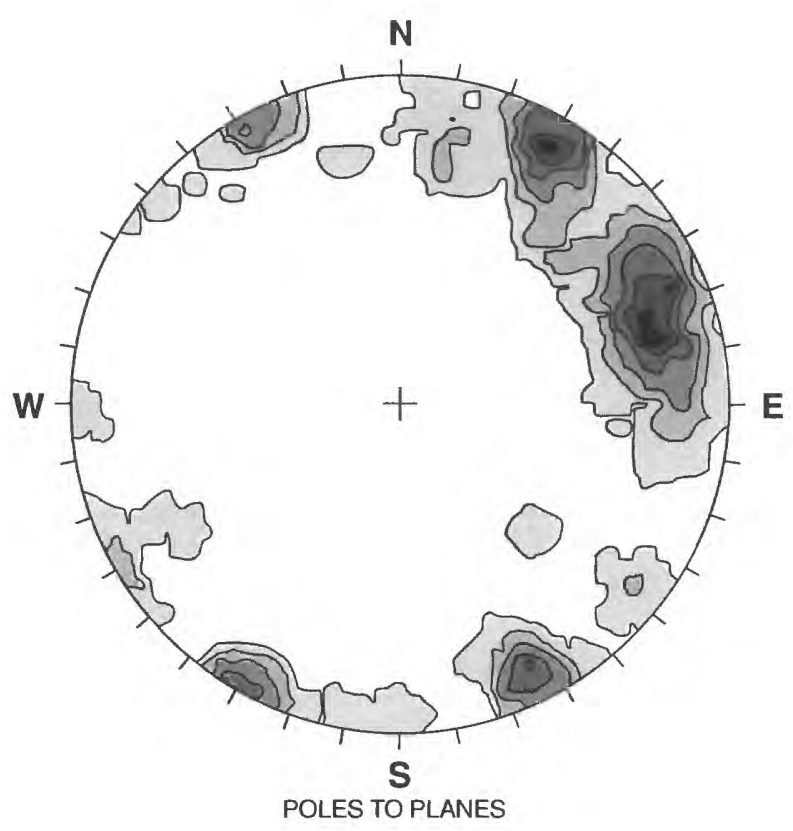

CONTOUR PLOT

SCHMIDT POLE

CONCENTRATIONS

$\%$ of total per

$1.0 \%$ area $\%$

$<1.67 \%$

$<3.33 \%$

$<5 \quad \%$

$<6.67 \%$

$<8.33 \%$

$<10 \%$

$<$ more

EQUALANGLE

LOWER HEMISPHERE

124 POLES

124 ENTRIES

NO BIAS

CORRECTION

POLES TO PLANES

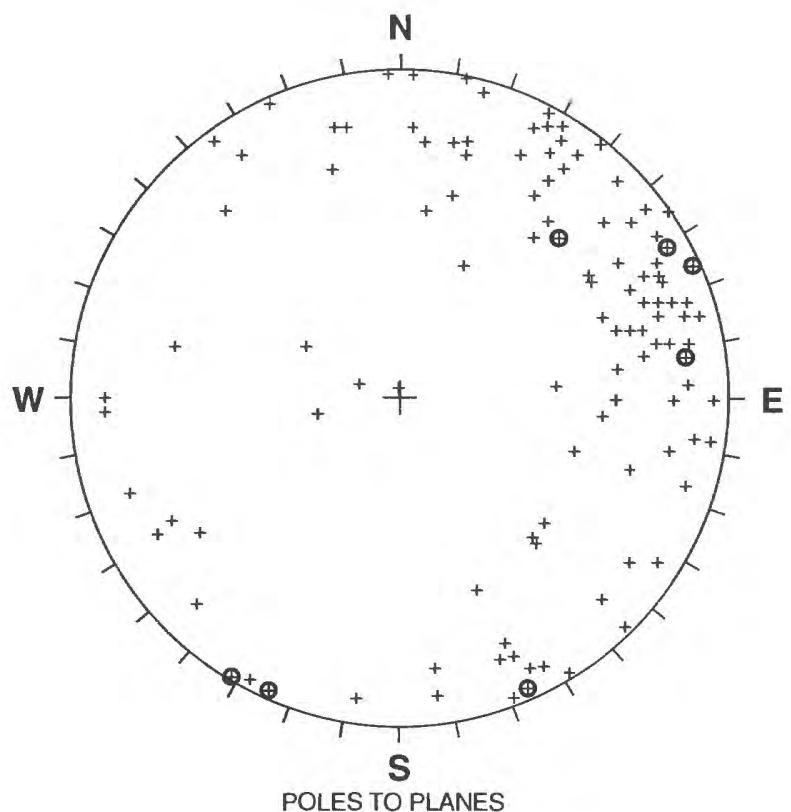

SCATTER PLOT NUMBER OF

POLES

+1 pole

- 2 poles

EQUAL ANGLE

LOWER HEMISPHERE

124 POLES

124 ENTRIES

Figure 4e. Equal-area density-contour Schmidt pole and scatter plots for mapped fracture locations. A. Left wall. B. Right wall. C. Box cut. D. Drain cut. E. Alcove \#1. F. NRG-1 pavement-Continued. 

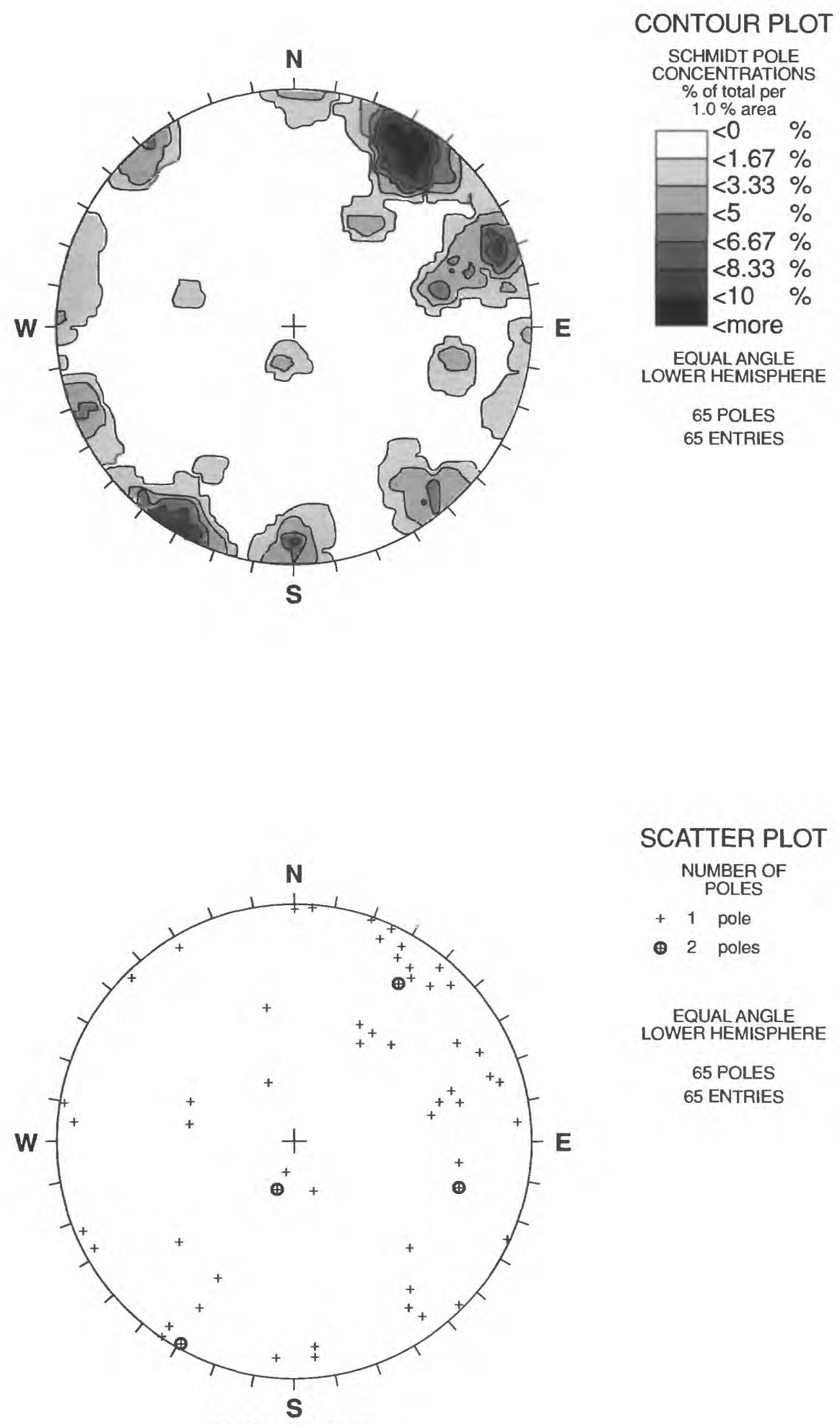
SCATTER PLOT
NUMBER OF
POLES
+1 pole
$\oplus 2$ poles

EQUAL ANGLE LOWER HEMISPHERE

65 POLES

65 ENTRIES

POLES TO PLANES

Figure 4f. Equal-area density-contour Schmidt pole and scatter plots for mapped fracture locations. $A$. Left wall. B. Right wall. C. Box cut. D. Drain cut. E. Alcove \#1. F. NRG-1 pavement-Continued. 


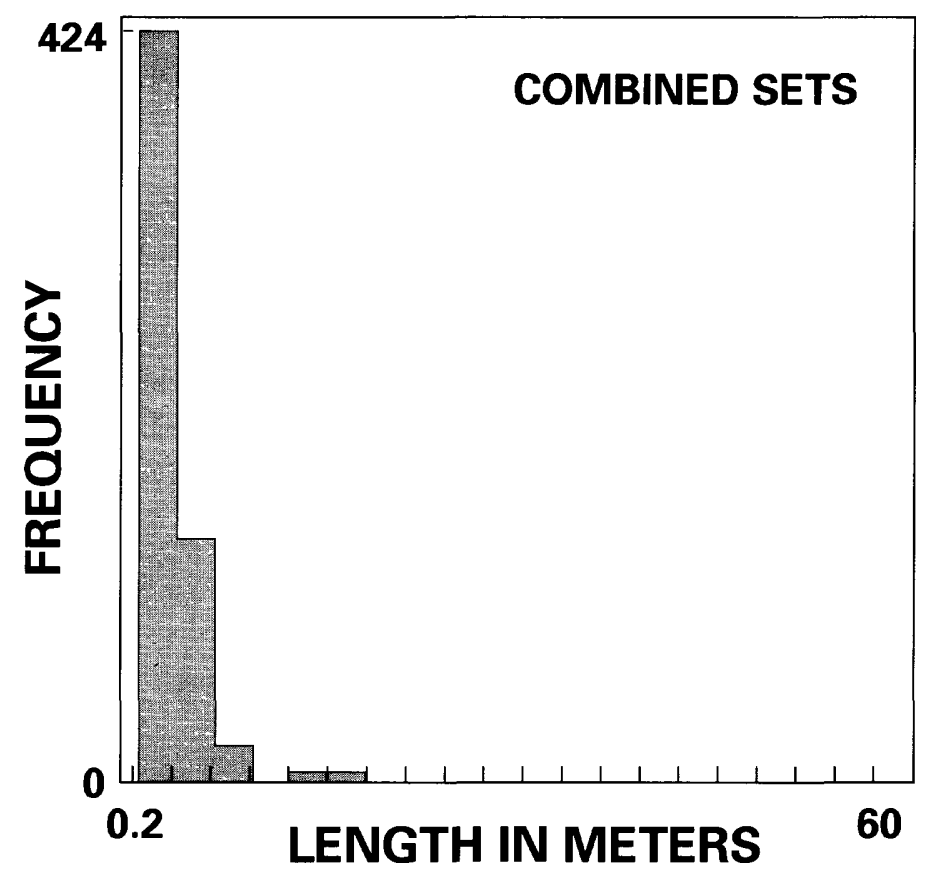

Figure 5. Mapped fracture trace lengths for combined sets 1-4, starter tunnel area.

sampling of the total borehole. Also, depth from the land surface to the boreholes is approximately $25 \mathrm{~m}$. This short distance could result in fractures being influenced by near-surface conditions that could affect aperture, intensity, and orientation. Because there were no fracture-orientation data and limited frequency data associated with these boreholes, no permeability and orientation, nor permeability and frequency relations could be compared.

\section{Orientation Analysis}

The generation of natural fractures is affected by regional and local stress fields. Fractures usually occur in sets and can be distinguished by numerous criteria; the most common is orientation. Other factors such as length, mineral coatings, aperture, and roughness can be used, but these other factors except for orientation and length would be difficult to map and synthesize at scales used in this study. Because regression analysis showed that there was no apparent relation between length and orientation, orientation was used as the only set criterion.

From mapped data, fracture sets were determined using the ISIS module in FracMan (Dershowitz and others, 1994). From an initial estimate of the number of sets and their mean orientation the distribution of orientation for each set is calculated in ISIS. The program then reassigns the sets according to probabilistic pattern recognition and probabilistic weights proportional to their similarity to other orientations in the set. The process is repeated until the set assignment is optimized. Dispersion and strength (percentage of fractures) for each set is determined based on the outcome of set optimization. The number of sets and mean orientations are finalized when the orientations for each set are repeatable using different starting sets and different starting orientation estimates. Input sequence for the sets is based on termination relations. The number and mean orientation of sets visually determined from mapped data do not necessarily have to fit exactly with the statistically generated number and orientation from the ISIS subroutine. A few fractures may be included as part of the dispersion (scatter) of other sets.

Other parameters that are included as output from the statistical analysis are dispersion and strength. Dispersion $(\mathrm{k})$ is a concentration parameter around a mean in a Fisher distribution (Fisher, 1953). For $\mathrm{k}=0$, orientations are randomly distributed, and for a large $\mathrm{k}$, orientations are tightly concentrated around the mean. Strength represents the percentage of fractures in a par- 
ticular set compared to the total number of fractures in the data set. Results show there are four sets: N. $7^{\circ} \mathrm{W}$., $75^{\circ}$ W.; N. $47^{\circ}$ W., $83^{\circ}$ SW.; N. $60^{\circ}$ E., $86^{\circ}$ NW.; and N. $16^{\circ} \mathrm{W} ., 15^{\circ} \mathrm{SW}$. (table 2 ). Figure 7 shows equalarea Schmidt pole scatter plots of fractures in each set determined from the ISIS subroutine. The method determined the best fit trend and plunge. The first three sets generally parallel major fault trends. The fourth set consists of residual fractures that could not fit into the first three sets.

\section{Size Analysis}

Fracture size is defined as the effective fracture radius (Dershowitz and others, 1991) and can be determined from mapped trace lengths. The method uses FracSize, a module in FracMan, (Dershowitz and others, 1994). FracSize uses a forward modeling approach where the radius and distribution are determined by probabilistic censoring. That is, the calculated radii and distribution are matched to the observed tracelength data (table 3). An assumed radius distribution is varied to improve the confidence level that the statistical match between the simulated and measured lengths is valid. This method eliminates bias in the length data by determining a fracture radius and accounting for censoring and truncation by matching simulated and matched distributions (assuming that the mapping plane is large enough to capture a certain percentage of fracture end points).

\section{Fracture Intensity Analysis}

There are many measures of fracture intensity, but the preferred method in this study is fracture area to rock volume, $\mathrm{m}^{2} / \mathrm{m}^{3}$ (annotated by the term P32). Other important intensity measures are total fracture length per area (P21) and the number of fractures per length (P10 or $\lambda)$. Intensities $\mathrm{P} 32$ and $\mathrm{P} 21$ are scale invariant and include a length or size factor. In most cases, fracture size is one of the most important factors in establishing a percolation threshold. In their simulation of flow in three-dimensional networks of discrete fractures, Andersson and Dverstorp (1987) concluded that a network of small fractures will conduct less water than a network of large fractures even if the density of the small fracture network is much larger than the density of the large fracture network.

Intensity P32 cannot be measured, but is determined by a three-step process: (1) estimate a P32 and simulate a stochastically generated fracture network; (2) refine the estimated P32 value by calculating a ratio of P21 and P10 measured values to values calculated from the initial simulation. The mapped intensities are from the right and left walls of the starter tunnel and alcove \#1. Simulated intensities of $P 21_{\text {sim }}$ and $P 10_{\text {sim }}$ were determined from trace planes and line surveys inserted into the simulated network with the same length and orientation as were the mapped areas; and (3) the refined P32 value is randomly changed until $\mathrm{P} 21_{\text {sim }}$ equals or nearly equals $\mathrm{P} 21_{\text {mapped }}$ and $\mathrm{P} 10_{\text {sim }}$ equals or nearly equals $\mathrm{P} 10_{\text {mapped. }}$. Table 4 shows the comparison. Most mapped mean intensities fall within one standard deviation of the simulated values. As a result, initial intensity, $\mathrm{P} 32_{\mathrm{I}}$, for the starter tunnel area is $1.00 \mathrm{~m}^{2} / \mathrm{m}^{3}$.

\section{Spatial Model}

Although fracture data mapped in the starter tunnel and surrounding area and in the ESF have been registered spatially, no comprehensive analysis is available to determine a spatial model. Air-permeability values from packer tests in alcove \#1 give results too inconclusive to determine any spatial correlation. Because the starter tunnel and the ESF are "dry," no determination could be made between conductive and nonconductive fractures. Therefore, the DFN models for this project represent fractures as planar and elliptically shaped polygons that have centers that are randomly located in space, described by a stationary Poisson point process (Dershowitz and others, 1994). Fracture networks are generated stochastically as realizations of randomly located fracture sets.

\section{Conductive Network Simulation}

An objective of modeling discrete fractures is to identify and map fractures that are connected to each other. The original simulated fracture network has numerous small fractures that are unconnected, do not contribute to the flow system, and are computationally inefficient. For the purpose of this study, unconnected fractures are considered storage and contribute nothing to the flow system. A conductive or connected fracture network from the initial simulated network is based on an approach developed by Osnes and others (1988) and incorporated into OxFilet, a module in FracMan code (Dershowitz and others, 1994). The approach assumes that the net transmissivity of a packer zone is equal to the sum of the transmissivities of the conductive fractures that intersect the packer zone in the borehole for 
Table 2. Input parameters for discrete fracture network model, starter tunnel area

[Dispersion, $k$, amount of scatter around a mean in a Fisher distribution, the smaller number indicates more scatter; termination percentage is for $T$ type terminations; strength percentage, percentage of fractures in a set; P32, intensity of fracture area to rock volume, in square meter per cubic meter; bootstrap, uses mapped fracture orientations instead of generated Fisher orientations]

\begin{tabular}{|c|c|c|c|c|c|c|c|c|c|c|c|}
\hline \multirow[b]{2}{*}{ Set } & \multicolumn{4}{|c|}{ Orientation } & \multicolumn{4}{|c|}{ Size } & \multirow[b]{2}{*}{$\begin{array}{l}\text { Termination } \\
\text { percentage }\end{array}$} & \multirow[b]{2}{*}{$\begin{array}{c}\text { Strength } \\
\text { percentage }\end{array}$} & \multirow[b]{2}{*}{$\begin{array}{c}\text { Intensity } \\
\text { P32 }\end{array}$} \\
\hline & $\begin{array}{c}\text { Pole } \\
\text { (trend, } \\
\text { plunge) }\end{array}$ & $\begin{array}{l}\text { Azimuth } \\
\text { (trend, } \\
\text { plunge) }\end{array}$ & $\begin{array}{c}\text { Dispersion, } \\
\text { k }\end{array}$ & Type & $\begin{array}{c}\text { Mean } \\
\text { (meters) }\end{array}$ & $\begin{array}{c}\text { Standard } \\
\text { deviation } \\
\text { (meters) }\end{array}$ & Type & $\begin{array}{c}\text { Minimum/ } \\
\text { maximum } \\
\text { cutoff } \\
\text { (meter) }\end{array}$ & & & \\
\hline 1 & 083,15 & $\begin{array}{l}\text { N7W, } \\
75 W\end{array}$ & 20.3 & Fisher & 2.85 & 1.67 & LogNormal & $0.71 / 100$ & 0 & 0.322 & 0.322 \\
\hline 3 & 150,04 & $\begin{array}{l}\text { N60E, } \\
86 \mathrm{NW}\end{array}$ & 9.8 & Fisher & 2.39 & 1.51 & LogNormal & $.71 / 100$ & 45 & .292 & .292 \\
\hline 4 & 254,75 & $\begin{array}{l}\text { N16W, } \\
15 \mathrm{SW}\end{array}$ & 13.4 & $\begin{array}{l}\text { Boot- } \\
\text { strap }\end{array}$ & 1.00 & 1.8 & Exponential & $1.00 / 100$ & 0 & .143 & .143 \\
\hline
\end{tabular}

Table 3. FracSize simulation results to determine fracture size from mapped trace lengths, starter tunnel area

$[--$, not applicable $]$

\begin{tabular}{|c|c|c|c|c|c|c|}
\hline \multirow{2}{*}{ Parameter } & \multicolumn{2}{|c|}{ Set 1} & \multicolumn{2}{|c|}{ Set 2} & \multicolumn{2}{|c|}{ Set 3} \\
\hline & Simulation & Data & Simulation & Data & Simulation & Data \\
\hline Number of data points & 220 & 218 & 165 & 165 & 200 & 198 \\
\hline Size distribution type & LogNormal & - & LogNormal & -- & LogNormal & -- \\
\hline Mean size, in meters & 2.85 & 3.02 & 2.51 & 2.78 & 2.39 & 2.33 \\
\hline Standard deviation, in meters & 1.67 & 3.32 & 1.38 & 3.2 & 1.51 & 1.82 \\
\hline Smirnov, percent significance & 40.8 & -- & 34.5 & -- & 51.7 & -- \\
\hline Chi-squared, percent significance & 75.7 & -- & 42.8 & -- & 97.7 & -- \\
\hline
\end{tabular}

Table 4. Intensity and termination values from line and area surveys

$\left[P 21\right.$, intensity of fracture length in meters to square meter $\left(\mathrm{m} / \mathrm{m}^{2}\right) ; \mathrm{P} 10$, intensity of number of fractures per meter $(\mathrm{m}) ; \mathrm{S}$, simulated; M, mapped; $\mu$, mean; $\sigma$, one standard deviation; --, no analysis]

\begin{tabular}{|c|c|c|c|c|c|c|}
\hline \multirow{3}{*}{ Line or area survey } & \multicolumn{4}{|c|}{ Intensity } & & \\
\hline & \multicolumn{2}{|c|}{$\begin{array}{c}\text { P21 } \\
\left(\mathrm{m} / \mathrm{m}^{2}\right)\end{array}$} & \multicolumn{2}{|c|}{$\begin{array}{c}\text { P10 } \\
\text { (number fractures } / \mathrm{m} \text { ) }\end{array}$} & \multicolumn{2}{|c|}{ Termination percent } \\
\hline & $\overline{\mathbf{S}}$ & $\overline{\mathbf{M}}$ & $\mathbf{S}$ & $\mathbf{M}$ & $\mathbf{S}$ & $\mathbf{M}$ \\
\hline Right wall & $\mu=1.04$ & 1.02 & $\mu=0.98$ & 1.06 & $\mu=22.1$ & 20.0 \\
\hline & $\sigma=0.15$ & -- & $\sigma=0.11$ & - & $\sigma=8.9$ & -- \\
\hline \multicolumn{7}{|c|}{ Alcove I } \\
\hline Right wall & $\mu=0.94$ & .92 & $\mu=0.89$ & .99 & $\mu=14.3$ & 10.0 \\
\hline & $\sigma=0.22$ & -- & $\sigma=0.16$ & -- & $\sigma=17.0$ & -- \\
\hline Left wall & $\mu=1.02$ & .60 & $\mu=0.96$ & .68 & $\mu=14.7$ & 7.0 \\
\hline & $\sigma=0.25$ & -- & $\sigma=0.16$ & -- & $\sigma=12.3$ & -- \\
\hline Middle FSU & $\mu=0.87$ & .70 & $\mu=0.52$ & 1.17 & -- & -- \\
\hline & $\sigma=0.09$ & -- & $\sigma=0.08$ & - & -- & -- \\
\hline Lower FSU & $\mu=0.94$ & .98 & $\mu=0.52$ & 1.52 & -- & -- \\
\hline & $\sigma=0.11$ & -- & $\sigma=0.08$ & -- & - & - \\
\hline
\end{tabular}


a given initial frequency, $\lambda_{\mathrm{I}}(\mathrm{P} 10)$. Packer interval transmissivities are simulated for different frequencies and transmissivity distributions until a statistically valid match is made between the field and simulated transmissivity distributions (table 5). The optimized fracture frequency, $\lambda_{C}$, then represents a frequency of a connected network. Even though $\lambda_{\mathrm{C}}$ is not a unique value, it is an attempt to define the smallest frequency that represents the field data.

Converted transmissivity data from the three radial boreholes in alcove \#1 are shown in figure 6 (G.D. LeCain, written commun., 1995). Using the OxFilet method described above, $\lambda_{C}=0.74$, and the transmissivity of individual fractures are calculated to be lognormally distributed with a mean of $9.25 \times 10^{-11}$ $\mathrm{m}^{3}$ and standard deviation of $1.31 \times 10^{-10} \mathrm{~m}^{3}$ (table 5). A cutoff transmissivity of $7.10 \times 10^{-12} \mathrm{~m}^{3}$ was used to indicate packer intervals that are defined as nonconductive. Even though all field-derived permeabilities are relatively high, using this minimum value in the analysis showed that 32.5 percent of the simulated packer intervals were nonconductive (table 5), which is optimal for this analysis. The connected fracture frequency is then used to calculate a connected fracture intensity, $P 32_{C}$, that is representative of a connected network.

Other hydraulic parameters were assigned to each fracture in a specific fracture set as part of the fracture network simulation. These parameters include storage and aperture. Storage was input as a lognormal distribution with a mean of $1.0 \times 10^{-6}$, and a standard deviation of $1.0 \times 10^{-6}$. Apertures can be calculated by two methods: by direct measurement and by inference from knowing the permeability and calculating an aperture from the cubic law (Witherspoon and others, 1980). Aperture distributions from direct measurements are extremely difficult to evaluate, however, because point measurements rarely, if ever, represent the overall effective or hydraulic aperture. As a result, the range and distribution of effective apertures is speculative. Another technique is to calculate aperture from sonic velocity measurements (Schlumberger, 1972) to derive fracture porosity and aperture from cores (Anderson, 1984; 1991). Using this method, aperture calculations ranged from 100 to $2,200 \mu$, with a mean of $500 \mu$. Also, open apertures measured in the ESF range from less than one to $70,000 \mu$. At this time, it is unknown if these large openings are a rare occurrence or contribute to the geometric configuration of fast pathways. Apertures calculated from the cubic law method range from 100 to $300 \mu$. Apertures were cal-
Table 5. Oxfilet simulation results for individual fractures. Data are from converted transmissivity values in radial boreholes, alcove \#1, starter tunnel area

[--, not applicable]

\begin{tabular}{lcc}
\hline \multicolumn{1}{c}{ Parameter } & Simulation & Data \\
\hline Number of data points & 20 & 20 \\
$\begin{array}{l}\text { Minimum transmissivity, in cubic } \\
\quad \text { meters }\end{array}$ & $7.10 \times 10^{-12}$ & -- \\
Percentage nonconductive & 32.5 & 30 \\
Transmissivity distribution type & LogNormal & LogNormal \\
Mean transmissivity, in cubic & $9.25 \times 10^{-11}$ & -- \\
$\quad$ meters & & \\
Standard deviation, in cubic meters & $1.31 \times 10^{-10}$ & -- \\
Number of fractures per meter & .74 & -- \\
Smirnov, percent significance & 92.5 & -- \\
Chi-squared, percent significance & 49.8 & -- \\
\hline
\end{tabular}

culated to help evaluate the geometric character of the fracture network. Aperture was input as a lognormal distribution with a mean of $500 \mu$ and a standard deviation of $500 \mu$.

\section{Fracture Intensity Analysis}

The connected fracture intensity, $\mathrm{P} 32_{\mathrm{C}}$, is based on a ratio of initial $P 32_{\mathrm{I}}$, and initial $\lambda_{\mathrm{I}}$, and is given by the equation

$$
P 32_{C}=\frac{P 32}{\lambda_{I}} \lambda_{C}
$$

where $\lambda_{C}$ is the optimized conductive fracture frequency. The initial fracture frequency, $\lambda_{\mathrm{I}}$ of the simulated network was derived from calculating fracture frequencies from a horizontal borehole of some length. This procedure is repeated for several realizations and from different spatial positions. The mean frequency that was calculated was used as the initial frequency.

From equation 1 , and $\mathrm{P} 32_{\mathrm{I}}=1.0 \mathrm{~m}^{2} / \mathrm{m}^{3}, \lambda_{\mathrm{I}}=$ 0.96 fractures per $\mathrm{m}$, and $\lambda_{\mathrm{C}}=0.74$ fractures per $\mathrm{m}$, then $\mathrm{P} 32_{\mathrm{C}}=0.77 \mathrm{~m}^{2} / \mathrm{m}^{3} . \mathrm{P} 32_{\mathrm{C}}$ is then used as input to simulate a connected network. Initial fracture sets and their input parameters do not change. Once a connected fracture network is finalized, the fracture network can be further analyzed including the number of connected networks and pathways, size of blocks between fractures, and flow simulations. 


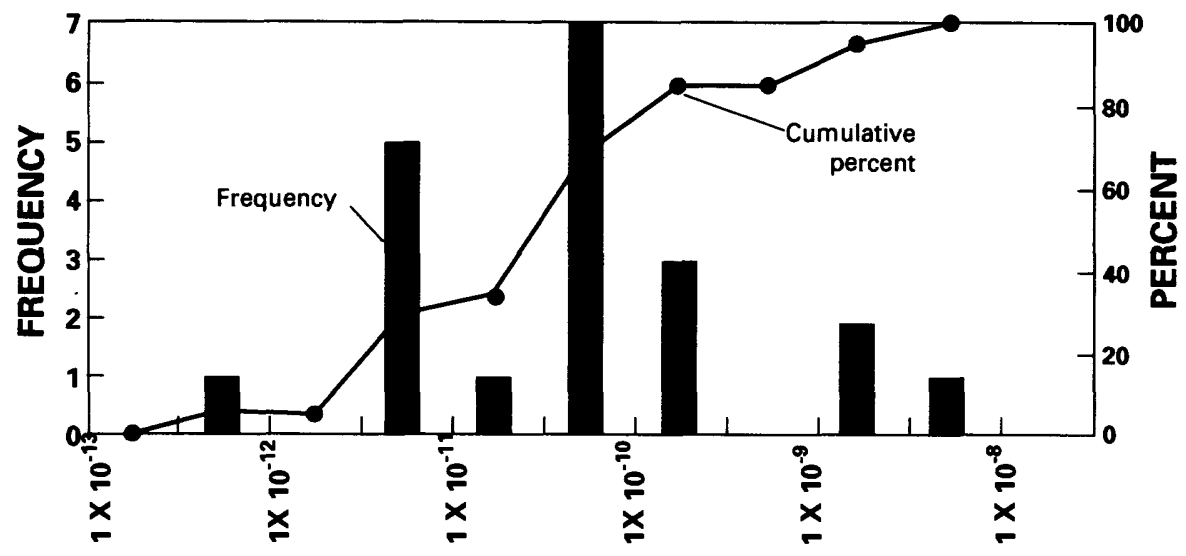

TRANSMISSIVITY, IN METERS CUBED

Figure 6. Distribution of airtransmissive values measured in radial boreholes, alcove \#1, starter tunnel area.

\section{Network Analysis}

Network analysis defined the number of fractures that were connected to the three boreholes in alcove \#1 for simulation area 5 (fig. 2). The analysis showed that an average of 422 fractures were generated, and boreholes 1,2 , and 3 had an average of 20.0, 21.7 , and 21.0 single fracture intersections, respectively (table 6). That is an average of about 0.70 fractures per meter. An average of 53 networks (a network is one or more than one connected fractures) were connected to at least one of the boreholes.

Table 6. Results of network analysis, radial boreholes, alcove \#1, starter tunnel area

[RBH, radial borehole]

\begin{tabular}{|c|c|c|c|c|c|}
\hline & \multirow{2}{*}{$\begin{array}{c}\text { Total } \\
\text { number } \\
\text { of } \\
\text { fractures }\end{array}$} & \multirow{2}{*}{$\begin{array}{c}\text { Total } \\
\text { number } \\
\text { of } \\
\text { networks }\end{array}$} & \multicolumn{3}{|c|}{$\begin{array}{c}\text { Number of fracture } \\
\text { intersections }\end{array}$} \\
\hline & & & RBH 1 & RBH 2 & RBH 3 \\
\hline Mean & 422 & 53 & 20.0 & 21.7 & 21.0 \\
\hline $\begin{array}{l}\text { Standard } \\
\text { deviation }\end{array}$ & 51 & 11 & 4.8 & 3.3 & 4.0 \\
\hline
\end{tabular}

\section{Pathway Analysis}

Pathway analysis is similar to the network analysis but determined the number of connections between boreholes. Results show that from borehole 3 (source) to boreholes 1 and 2 (sinks), out of 20 realizations, there are 6 showing no connections, 4 single pathway connections, and 10 two pathway connections. The single pathway averaged 3 fractures per pathway, and the two pathway network averaged 4 fractures per pathway. Thus, the connectivity between boreholes is sparse. Subsequent cross-borehole field testing (G.D. LeCain, written commun., 1995) showed no pneumatic response in any two boreholes when air was injected into a third. The nonpressure response may be attributed to other factors, such as borehole effects, or because extremely high transmissivities bleed pressures away from the boreholes. Even so, the results show that connectivity between boreholes may be extremely limited.

\section{Rock Block Analysis}

Rock block analysis defines the distribution of blocks bounded by fractures that divide the fracture network. The results (table 7) can be used to help calculate an average rock block size used in dual porosity simulations. The dimensions of the blocks are defined as the mean, standard deviation, and minimum and maximum block sizes for length, area, and volume measures. The block measures are defined based on

Table 7. Results of rock block analysis, starter tunnel area

\begin{tabular}{lccc}
\hline & $\begin{array}{c}\text { 1-Dimension } \\
\text { (meters) }\end{array}$ & $\begin{array}{c}\text { 2-Dimensions } \\
\text { (meters) }\end{array}$ & $\begin{array}{c}\text { 3-Dimensions } \\
\text { (meters) }\end{array}$ \\
\hline Mean & 1.6 & 27.0 & 38.2 \\
Standard deviation & 1.9 & 85.6 & 137 \\
Minimum & .14 & .10 & .0018 \\
Maximum & 13.0 & 597 & 614 \\
\hline
\end{tabular}



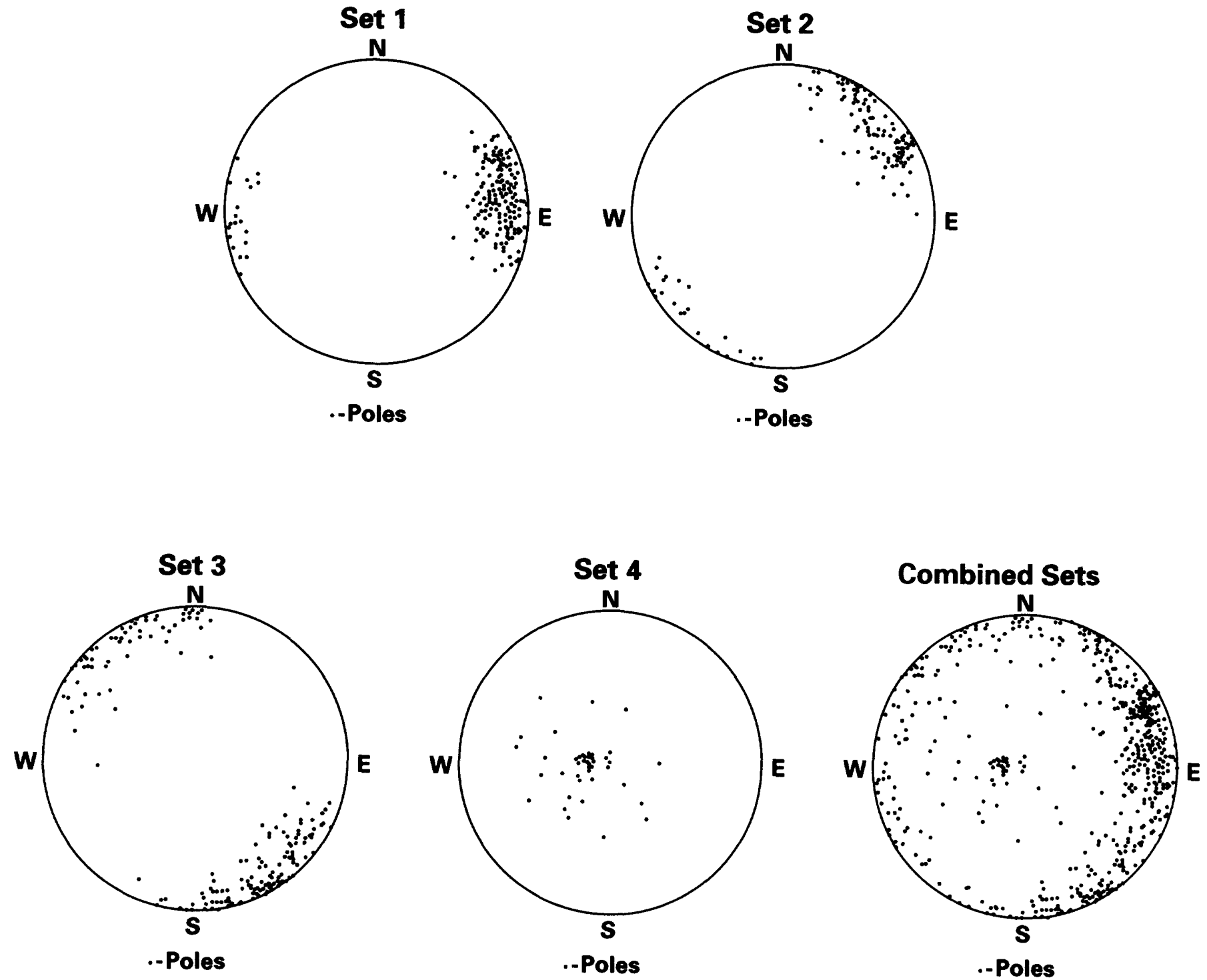

Figure 7. Equal-area Schmidt pole scatter plots for fracture sets 1 thru 4 and combined sets, starter tunnel area. 
lengths of randomly orientated rays located at randomly chosen points in the model. For each random location, one, two, or three rays are generated that are mutually orthogonal. For each ray, the distance from the starting location point and the first discrete fracture is computed

\section{MODEL OF DISCRETE FRACTURE NETWORK-TIVA CANYON TUFF}

Once a prototype fracture network was created for the starter tunnel area, the next step was to use the data and knowledge gained to expand the fracture network vertically and laterally, but did not include any specific spatial area of the Tiva Canyon Tuff. This approach was used because (1) only a limited amount of mapped data were available from the ESF and from boreholes; (2) the Tiva Canyon Tuff thickness in this area is highly variable; (3) the total Yucca Mountain area is too large for current computer capabilities; (4) data were not available to determine if the area was structurally homogeneous; and (5) uniform stress fields were thought to be operating over the entire area. Therefore, all units would have similar fracture sets, including orientation, disper- sion, size, and termination percentage. The percentage of each set, however, may vary spatially, and imposes a large degree of uncertainty.

Two fracture networks of the Tiva Canyon Tuff were simulated. Each network is $60 \mathrm{~m}$ thick (an average Tiva Canyon Tuff thickness) and consists of three fracture subunits (lower, middle, and upper), each $20 \mathrm{~m}$ thick (fig. 8). One network has edge lengths of $150 \mathrm{~m}$ and the other has edge lengths of $200 \mathrm{~m}$. Fracture input parameters (table 8) are the same for all subunits, except for intensity. Intensity was based on borehole fracture frequency and ESF data as described below.

\section{Orientation Analysis}

Fracture orientations for the Tiva Canyon Tuff fracture subunits were developed similar to the starter tunnel area. Orientation data were mapped from $60 \mathrm{~m}$ to $400 \mathrm{~m}$ of the ESF. Three fracture sets were defined using the ISIS method: N. $5^{\circ}$ W., $76^{\circ}$ W.; N. $54^{\circ}$ W., $79^{\circ} \mathrm{SW}$; and N. $38^{\circ}$ E., $89^{\circ}$ NW. Figure 9 shows an equal-area Schmidt pole plot for each fracture set.

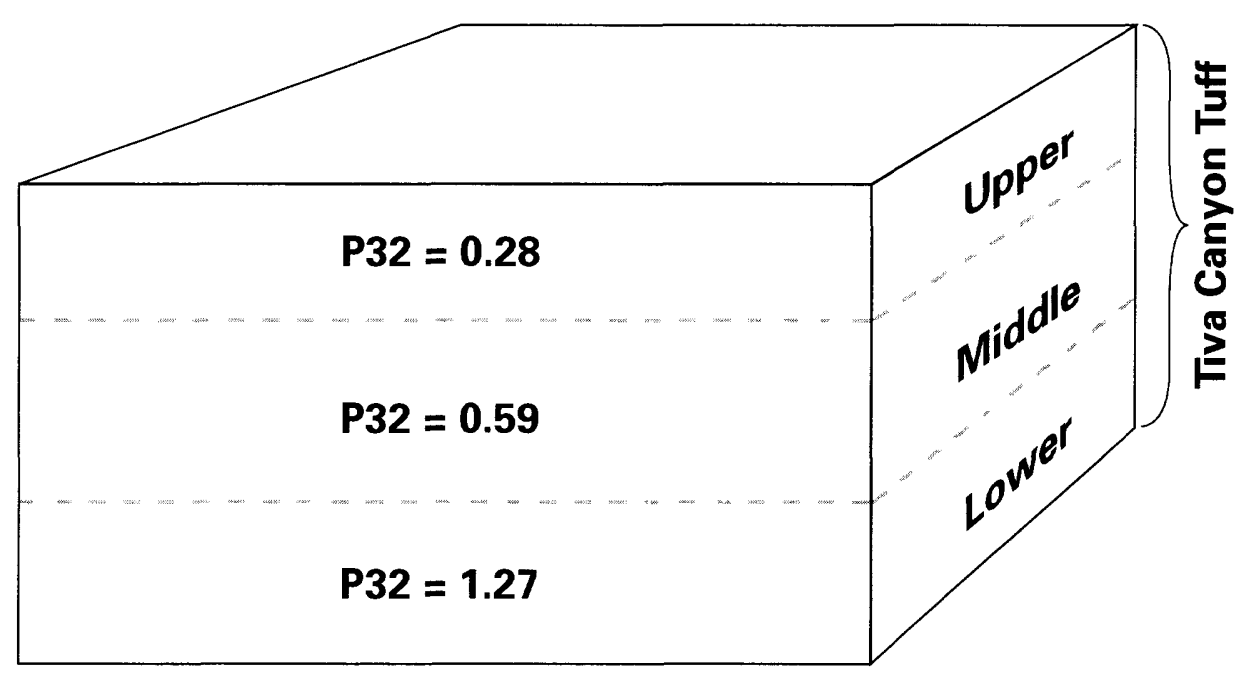

Figure 8. Network configuration and fracture intensities for each fracture subunit. 
Table 8. Fracture set parameters, Tiva Canyon Tuff, for all fracture subunits

[Dispersion, $\mathrm{k}$, amount of scatter around a mean in a Fisher distribution, the smaller number indicates more scatter ; termination percentage is for $T$ type terminations; strength percentage, percentage of fractures in a set; P32, intensity of fracture area to rock volume in square meter per cubic meter]

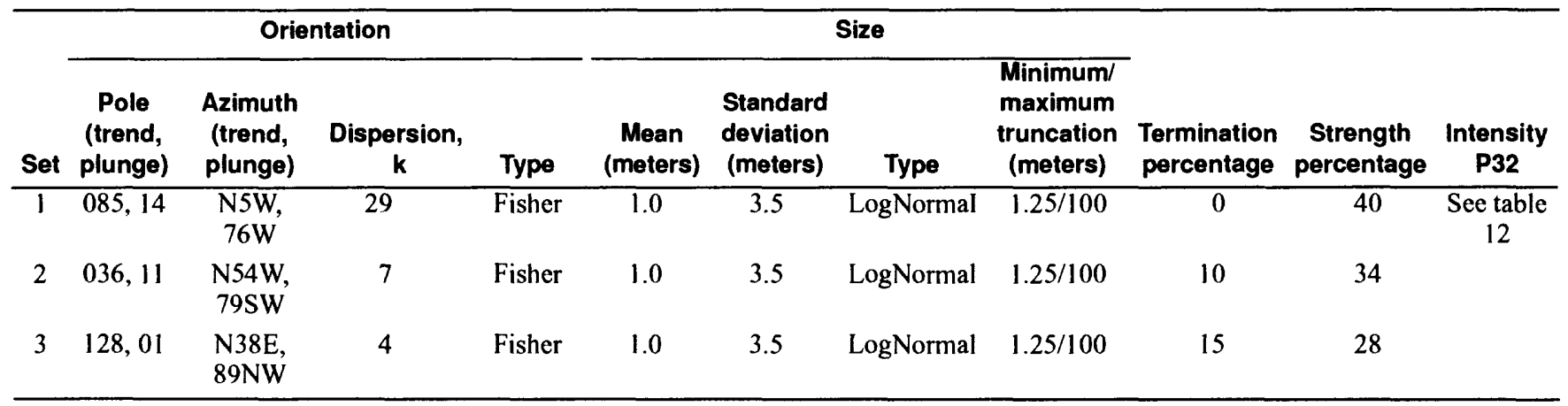

\section{Size Analysis}

Figure 10 shows uncorrected fracture lengths from mapping in the ESF for each set. The mapped fracture lengths were then converted to fracture size (table 8 ) by the FracSize method, similar to the method used for the starter tunnel.

\section{Fracture Intensity Analysis}

The initial fracture intensity for the Tiva Canyon Tuff, north ramp ESF, was calculated in a similar manner to the starter tunnel (ST) intensity calculations. A P2 1 mapped was calculated for each of the fracture subunit sections from the right and left walls of the ESF. Then the network was simulated with a P32 $2_{\text {sim }}$ value. $\mathrm{P} 21_{\text {sim }}$ values were calculated from simulated trace planes, and inserted into the network at the same size and orientation as the mapped wall. Equation 2 is used to calculate an initial ESF P32 ${ }_{\text {I }}$ intensity.

$$
P 32_{I}^{E S F}=\frac{P 32_{\text {sim }}}{P 21_{\text {sim }}} P 21_{\text {mapped }}
$$

Similar to the starter tunnel a connected network is the desired result for the DFN. With the starter tunnel's initial $\mathrm{P} 32_{\mathrm{I}}$ and conductive intensity $\mathrm{P} 32_{\mathrm{C}}$ and the ESF's initial intensity $\mathrm{P} 32_{\mathrm{I}}^{\mathrm{ESF}}$, a connected fracture intensity for the ESF can be calculated. This calculation is made with the assumption that the ratio of conductive to total fracture frequency is constant throughout the simulation region. This assumption is critical because for the Tiva Canyon Tuff, there are no wells with packer tests with enough data to determine a conductive frequency as was done for the starter tunnel area. An ESF $\mathrm{P} 32_{\mathrm{C}}$ then is calculated as a ratio of the starter tunnel
(ST) $\mathrm{P} 32_{\mathrm{C}}$ to the initial ST P32 times the ESF's initial $\mathrm{P} 32_{\mathrm{I}}$.

$$
P 32_{C}{ }^{E S F}=\frac{P 32_{C}{ }^{S T}}{P 32_{I}{ }^{S T}}\left(P 32_{I}{ }^{E S F}\right)
$$

All mapped and simulated P21 and P10 $(\lambda)$ intensity values are shown in table 9 . These values were used as input into calculating initial and connective P32 intensities as shown in table 9.

Both P21 and P10 intensities were used to calculate an initial and connected P32. The P21 value, however, was selected as the more robust of the two. Even so, the P10 value was calculated and used to compare results. Several vertical boreholes (fig. 1) were used to determine a mapped fracture frequency $(\mathrm{P} 10)$ value (table 10). However, these values overestimated P32 relative to the $\mathrm{P} 21$ method. To correct for the overestimation (1) a relation needed to be established between starter tunnel area mapped and simulated frequencies, and (2) a relation needed to be established between the number of fractures in vertical and horizontal borehole frequency values. These relations are necessary because borehole-mapped fractures are not censored by length. Therefore, borehole frequency was overestimated relative to tunnel or outcrop mapping, which is censored by length. Starter tunnel data (table 10) shows that there area about 75 percent more mapped fractures in a vertical borehole relative to the simulated number (because in boreholes, simulated fractures are length censored and mapped fractures are not). Starter tunnel data also shows that the ratio of horizontal to vertical borehole frequency is 2.04 . If the uncensored mapped values are used, $P 32$ values are underestimated (relative to the P21 method). If however, both the censored 

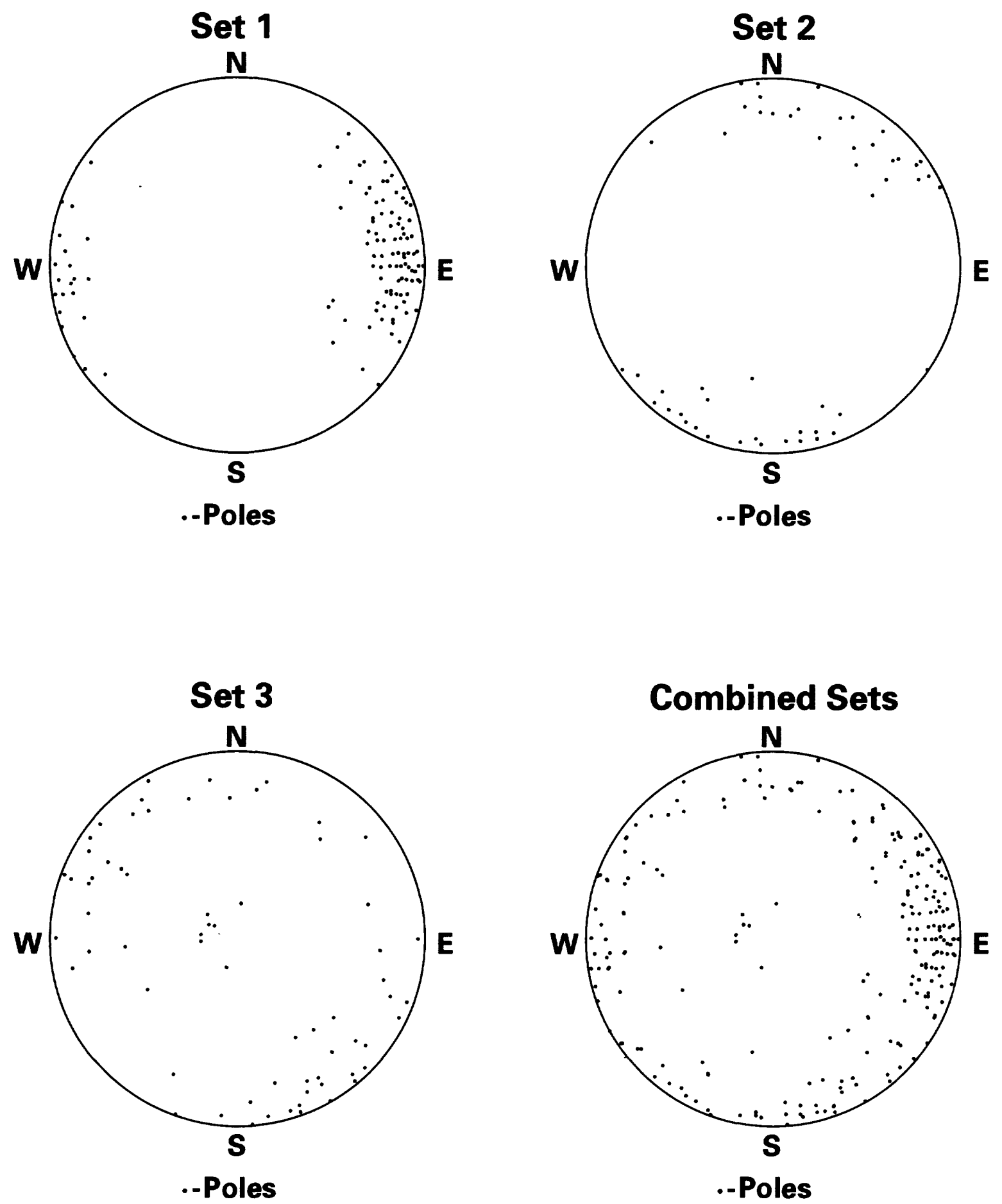

Figure 9. Equal-area Schmidt pole plots of mapped fractures for sets 1 through 3 and combined sets, Tiva Canyon Tuff 

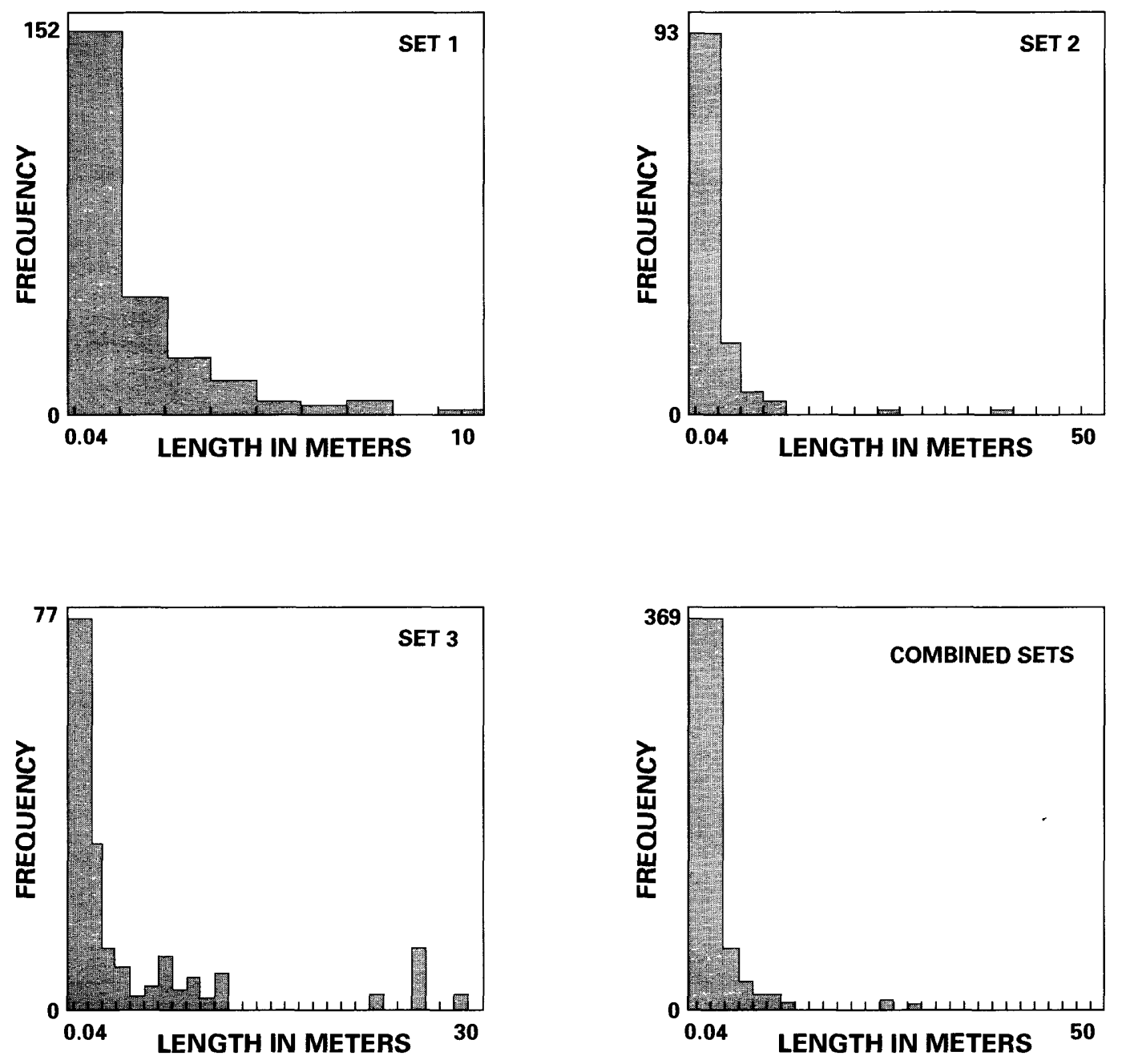

Figure 10. Mapped fracture lengths for sets 1 through 3 and combined sets, Tiva Canyon Tuff.

value and the horizontal frequency value are used, then the $P 32$ value is comparable to the $P 21$ method.

One fracture network will be generated with three contiguous slabs, each slab having its own unique P32 value (fig. 8). Fractures from each slab can penetrate into a contiguous slab rather than terminate at the boundary. Each slab will have its respective intensity, but all three slabs have similar fracture set parameters.

A visual comparison of simulated and mapped fractures was made using full periphery maps of the ESF (fig. 11). Even though the simulated map shows only one possible fracture geometry of the network, the visual similarity is close enough to provide confidence that the simulated network is consistent with the real network.

\section{Truncation of Small Fractures}

The number of fractures generated in this network is large enough to cause computational problems. Therefore, it is helpful to reduce the number of fractures in the system but keep the connected network intact. A numerical study was done to see what effect minimum truncation size had on the connectivity of a fracture network. Realizations were generated using randomly oriented fractures and length parameters that were lognormally distributed, a mean of $1.0 \mathrm{~m}$ and a standard deviation of $3.5 \mathrm{~m}$ (similar to the Tiva Canyon Tuff). The study was kept at a maximum truncation of $100 \mathrm{~m}$ constant while changing the minimum truncation and determining the effect on the number of pathways in the network. The first simulation had no truncation, but each new simulation increased its truncation size by $0.25 \mathrm{~m}$, up to $1.5 \mathrm{~m}$ (at the $1.5 \mathrm{~m}$ length, 
Table 9. Calculated initial $(I)$ and connected $(C)$ intensity values (P32) using the P21 and P10 methods, Tiva Canyon Tuff [P32, intensity of fracture area to rock volume, in square meter per cubic meter; I, initial, C, connected; P21, intensity of fracture length per meter squared; P10, number of fractures per meter; FSU, fracture subunit; --, not applicable]

\begin{tabular}{|c|c|c|c|c|c|c|c|c|}
\hline & & & \multirow{2}{*}{\multicolumn{2}{|c|}{$\begin{array}{c}\text { ESF } \\
\text { P21 method }\end{array}$}} & \multicolumn{4}{|c|}{ Tiva Canyon Tuff Area } \\
\hline & \multicolumn{2}{|c|}{$\begin{array}{l}\text { Starter tunnel } \\
\text { values }\end{array}$} & & & \multicolumn{2}{|c|}{$\begin{array}{l}\text { Censored P10 (M) } \\
\text { method }\end{array}$} & \multicolumn{2}{|c|}{$\begin{array}{c}\text { Uncensored P10 }(M) \\
\text { values }\end{array}$} \\
\hline & P32, & P32 $\mathrm{C}$ & P32, & $\mathbf{P 3 2}_{\mathrm{C}}$ & P32 & P32 $\mathrm{C}$ & P32 I & P32 $\mathrm{C}$ \\
\hline $\begin{array}{l}\text { Starter tunnel and alcove \#I } \\
\text { (middle FSU equivalent) }\end{array}$ & 0.86 & 0.77 & $-\cdots$ & -- & -- & -- & - & - \\
\hline Upper FSU & -- & -- & 0.59 & 0.53 & 0.39 & 0.29 & 1.52 & 1.14 \\
\hline Middle FSU & -- & -- & 1.26 & 1.13 & .76 & .56 & 2.94 & 2.15 \\
\hline Lower FSU & -- & -- & 2.71 & 2.43 & 1.27 & .93 & 4.90 & 3.58 \\
\hline
\end{tabular}

Table 10. Mapped, simulated, and calculated fracture data

[P10, number of fractures per meter; VBH, vertical borehole; HBH, horizontal borehole; --, not applicable; $\mu$, mean; $\sigma$, one standard deviation]

\begin{tabular}{|c|c|c|c|c|c|c|c|}
\hline \multirow[b]{2}{*}{$\begin{array}{c}\text { Fracture } \\
\text { subunit }\end{array}$} & \multicolumn{4}{|c|}{ Starter tunnel area } & \multicolumn{3}{|c|}{ Tiva Canyon Tuff } \\
\hline & $\begin{array}{c}\text { Simulated } \\
\text { mean P10, } \\
\text { VBH }\end{array}$ & $\begin{array}{c}\text { Simuated } \\
\text { mean P10, } \\
\text { HBH }\end{array}$ & $\begin{array}{l}\text { Mapped mean } \\
\text { P10, } \\
\text { area }\end{array}$ & $\begin{array}{c}\text { Censoring ratio } \\
\text { simulated P10/ } \\
\text { mapped P10 }\end{array}$ & $\begin{array}{c}\text { Mapped mean } \\
\text { P10, } \\
\text { VBH }\end{array}$ & $\begin{array}{c}\text { Censored } \\
\text { mapped mean } \\
\text { P10 VBH }\end{array}$ & $\begin{array}{c}\text { Derived mean } \\
\text { P10, } \\
\text { HBH }\end{array}$ \\
\hline Upper & -- & - & -- & -- & 1.63 & 0.42 & 0.86 \\
\hline Middle & $\begin{array}{l}\mu=0.47 \\
\sigma=0.08\end{array}$ & $\begin{array}{l}\mu=0.96 \\
\sigma=0.09\end{array}$ & 2.00 & 0.26 & $\begin{array}{l}\mu=2.94 \\
\sigma=1.03\end{array}$ & .76 & 1.56 \\
\hline Lower & -- & -- & -- & -- & $\begin{array}{l}\mu=4.90 \\
\sigma=2.90\end{array}$ & 1.27 & 2.60 \\
\hline
\end{tabular}

too few fractures were generated to provide reliable results). Therefore, with each new simulation, the smallest fractures were systematically removed. Fracture intensity was reduced so as not to bias the network. The intensity was reduced a proportional amount corresponding to the reduced area under the length distribution curve. For each simulation, a pathway analysis was done from one end of the generation box to the other. Results show that each simulation produced only one pathway, indicating that most fractures, that is, small fractures, did not contribute to the connectivity of the network. Even in two dimensions and at small scales, Odling (1995, p. 40) states that "even at high fracture densities, the flow properties of the fracture network are dominated by less than half the total fracture trace length." Therefore, minimum truncation of $1.25 \mathrm{~m}$ was chosen to develop the Tiva Canyon Tuff network, a $0.25 \mathrm{~m}$ increase over the mapped truncation amount of $1.0 \mathrm{~m}$. This small amount significantly reduces the number of short fractures, yet keeps the connectivity intact because nonconnected fractures orclusters represent dead-end porosity. Table 11 shows the intensities that were calculated using the initial and connected values for the $1.00-\mathrm{m}$ truncation and the $1.25-\mathrm{m}$ truncation.
Table 11. Initial $(I)$ and connected (C) fracture intensities for each fracture subunit, Tiva Canyon Tuff

$[\mathrm{P} 32$, intensity of fracture area per rock volume, in square meter per cubic meter; I, initial; C, connected]

\begin{tabular}{lccc}
\hline $\begin{array}{c}\text { Fracture } \\
\text { subunit }\end{array}$ & $\begin{array}{c}\mathbf{P 3 2} \\
\mathbf{1 . 0}-\text { meter } \\
\text { truncation }\end{array}$ & $\begin{array}{c}\mathbf{P 3 2} \mathrm{C} \\
\text { 1.00-meter } \\
\text { truncation }\end{array}$ & $\begin{array}{c}\mathbf{P 3 2}_{\mathrm{C}} \\
\mathbf{1 . 2 5}-\text { meter } \\
\text { truncation }\end{array}$ \\
\hline Upper & 0.81 & 0.53 & 0.13 \\
Middle & 1.56 & 1.13 & .25 \\
Lower & 2.60 & 2.43 & .42 \\
\hline
\end{tabular}

\section{Network and Pathway Analysis}

Network and pathway analysis determines the connectivity of the system. That is, how many fractures are connected to each other and do they form a continuous pathway from source to sink. For this study source and sink were opposite ends of the simulation area, similar to the flow simulations. Even in apparently well-connected fracture networks (the 150- and 200-m blocks), the connectivity is governed by only one pathway and constructed of only one to a few large fractures (tables 12 and 13). This analysis indicates that this network can be considered sparse. From numerous studies and observations, the paradigm that a small percentage of the fractures carry a large percentage of the fluid is 
A.

ESF North Portal-Right BenchTraceplate

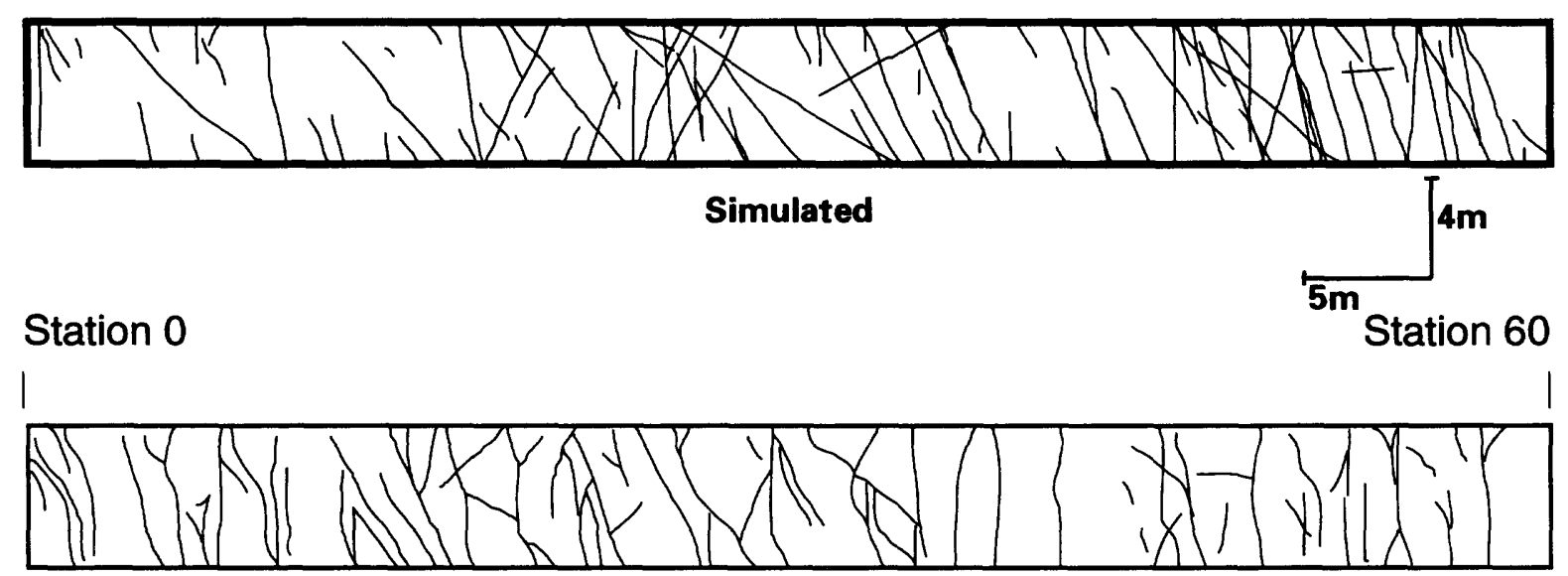

Mapped

B.

ESF North Portal-Left BenchTraceplane

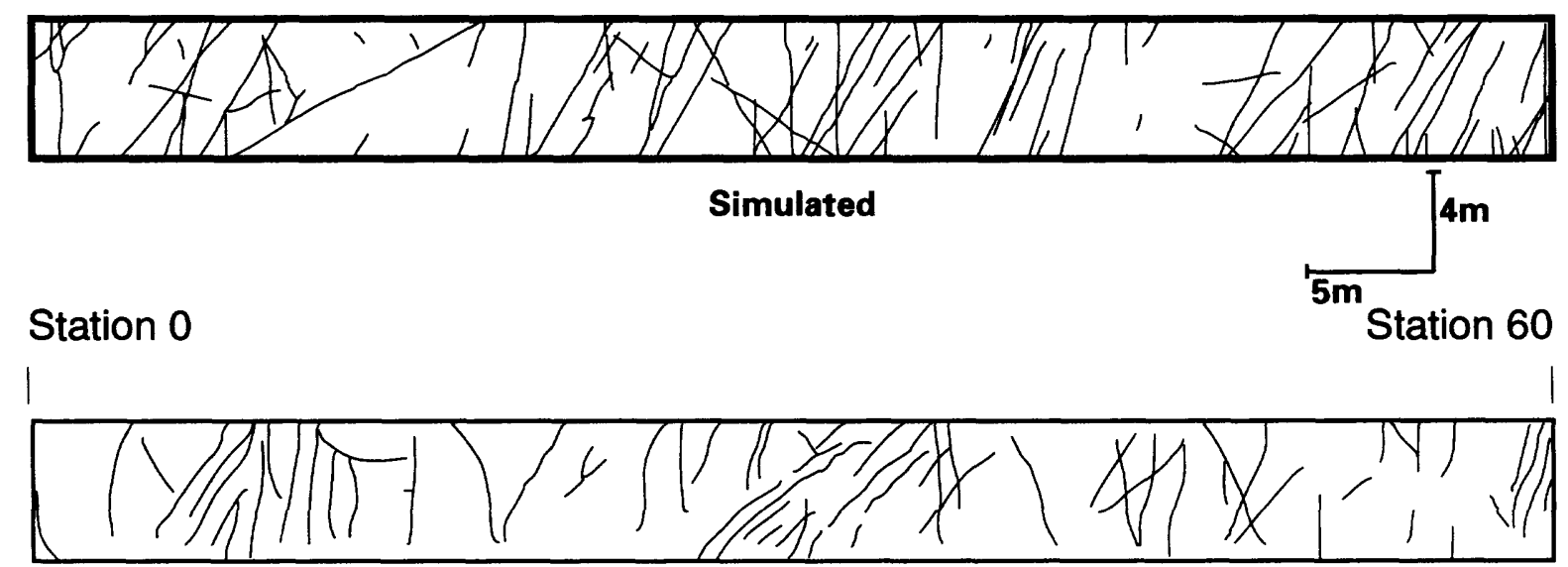

Mapped

Figure 11. Simulated and mapped fracture distributions in bench cut traceplanes in the starter tunnel. a, right bench; and b, left bench. 
Table 12. Network and pathway analysis for 150 -meter $\times 150$-meter $\times 60$-meter flow box

[Based on 10 realizations; $\mathrm{m}^{3} / \mathrm{s}$, cubic meters per second; $\mathrm{m}^{2}$, square meters]

\begin{tabular}{|c|c|c|c|c|c|c|c|c|}
\hline \multirow[b]{2}{*}{ Analysis from } & \multirow{2}{*}{$\begin{array}{l}\text { Average } \\
\text { number of } \\
\text { fractures }\end{array}$} & \multirow{2}{*}{$\begin{array}{l}\text { Average } \\
\text { number of } \\
\text { networks }\end{array}$} & \multirow{2}{*}{$\begin{array}{l}\text { Average } \\
\text { number of } \\
\text { pathways }\end{array}$} & \multirow{2}{*}{$\begin{array}{c}\text { Average number } \\
\text { of fractures in } \\
\text { pathway }\end{array}$} & \multicolumn{2}{|c|}{ Path conductance $\left(\mathrm{m}^{3} / \mathrm{s}\right)$} & \multicolumn{2}{|c|}{ Path area $\left(\mathrm{m}^{2}\right)$} \\
\hline & & & & & Mean & $\begin{array}{l}\text { Standard } \\
\text { deviation }\end{array}$ & Mean & $\begin{array}{l}\text { Standard } \\
\text { deviation }\end{array}$ \\
\hline East to west & 2515 & 1082 & 1 & Multiple & $4.84 \times 10^{-3}$ & $1.01 \times 10^{-2}$ & 8133 & 3962 \\
\hline South to north & 2515 & 1082 & 1 & Multiple & $9.77 \times 10^{-3}$ & $1.06 \times 10^{-2}$ & 4356 & 1743 \\
\hline SW to NE & 2515 & 1082 & 1 & Multiple & $6.25 \times 10^{-3}$ & $1.01 \times 10^{-2}$ & 4748 & 2768 \\
\hline
\end{tabular}

Table 13. Network and pathway analysis for 200 -meter $\times 200$-meter $\times 60$-meter flow box

[Based on 10 realizations; $\mathrm{m}^{3} / \mathrm{s}$, cubic meters per second: $\mathrm{m}^{2}$, square meters]

\begin{tabular}{|c|c|c|c|c|c|c|c|c|}
\hline \multirow[b]{2}{*}{ Analysis from } & \multirow{2}{*}{$\begin{array}{c}\text { Average } \\
\text { number of } \\
\text { fractures }\end{array}$} & \multirow{2}{*}{$\begin{array}{l}\text { Average } \\
\text { number of } \\
\text { networks }\end{array}$} & \multirow{2}{*}{$\begin{array}{l}\text { Average } \\
\text { number of } \\
\text { pathways }\end{array}$} & \multirow{2}{*}{$\begin{array}{c}\text { Average number } \\
\text { of fractures in } \\
\text { pathway }\end{array}$} & \multicolumn{2}{|c|}{ Path conductance $\left(\mathrm{m}^{3} / \mathrm{s}\right)$} & \multicolumn{2}{|c|}{ Path area $\left(\mathrm{m}^{2}\right)$} \\
\hline & & & & & Mean & $\begin{array}{l}\text { Standard } \\
\text { deviation }\end{array}$ & Mean & $\begin{array}{l}\text { Standard } \\
\text { deviation }\end{array}$ \\
\hline Top to bottom & 4187 & 1837 & 1 & Single & $1.41 \times 10^{-1}$ & $8.63 \times 10^{-2}$ & 1947 & 692 \\
\hline East to west & 4187 & 1837 & 1 & Multiple & $1.34 \times 10^{-2}$ & $3.89 \times 10^{-2}$ & 6591 & 3807 \\
\hline South to north & 4187 & 1837 & 1 & Multiple & $3.06 \times 10^{-3}$ & $4.77 \times 10^{-3}$ & 5231 & 2857 \\
\hline
\end{tabular}

valid because the number of fractures that are actually connected from source to sink is limited (very small scales excluded). The implications are that only a small percentage of the total fractures in the network may be involved in a particular flow path. Also, cross-borehole testing may have counter-intuitive results depending on distance between boreholes, size of source and sink packer intervals, and fracture size distribution and fracture orientation.

\section{BLOCK SCALE FLOW SIMULATIONS FOR THE TIVA CANYON TUFF}

The geometry of the fracture system controls the flow behavior of a rock volume for given boundary conditions and nearly impermeable rock matrix. The stochastically simulated fracture network of the Tiva Canyon Tuff, based in part on the prototype starter tunnel network, adequately replicates the connected fractures of the Tiva Canyon Tuff, even considering uncertainties of orientation, length, and spatial distribution.

Flow modeling of the Tiva Canyon Tuff can provide a distribution directional permeability for two flow box scales and can help evaluate the geometry of the fracture network. Even though the overall focus of this study is the unsaturated part of the Tiva Canyon Tuff, saturated flow conditions, using MAFIC flow code (Miller and others, 1994) are used to better meet the objectives of this preliminary flow model and to provide an initial evaluation of the geometry of the network. MAFIC was coupled to the fracture network model to simulate saturated flow conditions to help analyze the geometric configuration of the network and to determine directional permeabilities at various scales. For this study, network, pathway, and flow solutions are made only on the conductive or connected network. Nonintersecting fractures are eliminated automatically in the finite element meshing process. Once the fracture network is generated the next step is to generate a mesh on the fractures in order to numerically simulate flow.

The mesh generator, MeshMaker (Dershowitz and others, 1994) transforms fractures into meshes containing triangular finite elements. This transformation then allows the coupling of the flow code MAFIC (Miller and others, 1994) and the simulation of flow through the fracture network. 
Directional permeability, $\mathrm{K}_{\mathrm{g}}$, was calculated for $x, y$, and $z$ directions, where flux is calculated in the same direction as the head gradient. For a rock volume to behave isotopically, each directional permeability must be similar, that is, $\mathrm{Kxx}=\mathrm{Kyy}=\mathrm{Kzz} . \mathrm{K}_{\mathrm{g}}$ was calculated in the direction of gradient and is used to analyze the anisotropy of the rock volume using Darcy's law,

$$
K_{g}=\frac{Q_{g}}{A \nabla J}
$$

where $Q_{g}$ is the flux calculated from the finite element analysis, $\mathrm{A}$ is the gross area perpendicular to flow, and $\mathbf{J}$ is the gradient. Permeabilities were calculated for different scales, under saturated conditions.

Figure 12 shows the network region and flow box configuration. For each position of the flow box, head gradients were prescribed for a pair of opposite panels with other panels having no flow boundaries. Similar procedures were used in south to north, east to west, and top to bottom flow directions. The box was then rotated 45 degrees horizontally, keeping the fracture network fixed in space. Gradients were then prescribed from southwest to northeast and southeast to northwest, with no flow boundaries on all other panels.

Permeability values were calculated for 10 realizations for each flow direction and for each flow box size. The calculated bulk saturated directional permeabilities are listed in tables 14 and 15 .

Table 14. Bulk saturated directional permeabilities for 150 meter $\times 150$-meter $\times 60$-meter flow box, Tiva Canyon Tuff

[Based on 10 realizations, steady state simulations; $\mathrm{m}^{2}$, square meters]

\begin{tabular}{lcc}
\hline $\begin{array}{c}\text { Constant head } \\
\text { gradient from }\end{array}$ & \multicolumn{2}{c}{$\begin{array}{c}\text { Bulk saturated permeability } \\
\left(\mathrm{m}^{2}, \text { no matrix }\right)\end{array}$} \\
\cline { 2 - 3 } & Mean & Standard deviation \\
\hline Top to bottom & $2.657 \times 10^{-13}$ & $1.347 \times 10^{-13}$ \\
East to west & $2.805 \times 10^{-11}$ & $6.957 \times 10^{-12}$ \\
South to north & $2.285 \times 10^{-12}$ & $3.279 \times 10^{-13}$ \\
SE to NW & $1.308 \times 10^{-12}$ & $6.934 \times 10^{-13}$ \\
SW to NE & $1.093 \times 10^{-12}$ & $3.547 \times 10^{-13}$ \\
Geometric mean & $1.894 \times 10^{-12}$ & \\
\hline
\end{tabular}

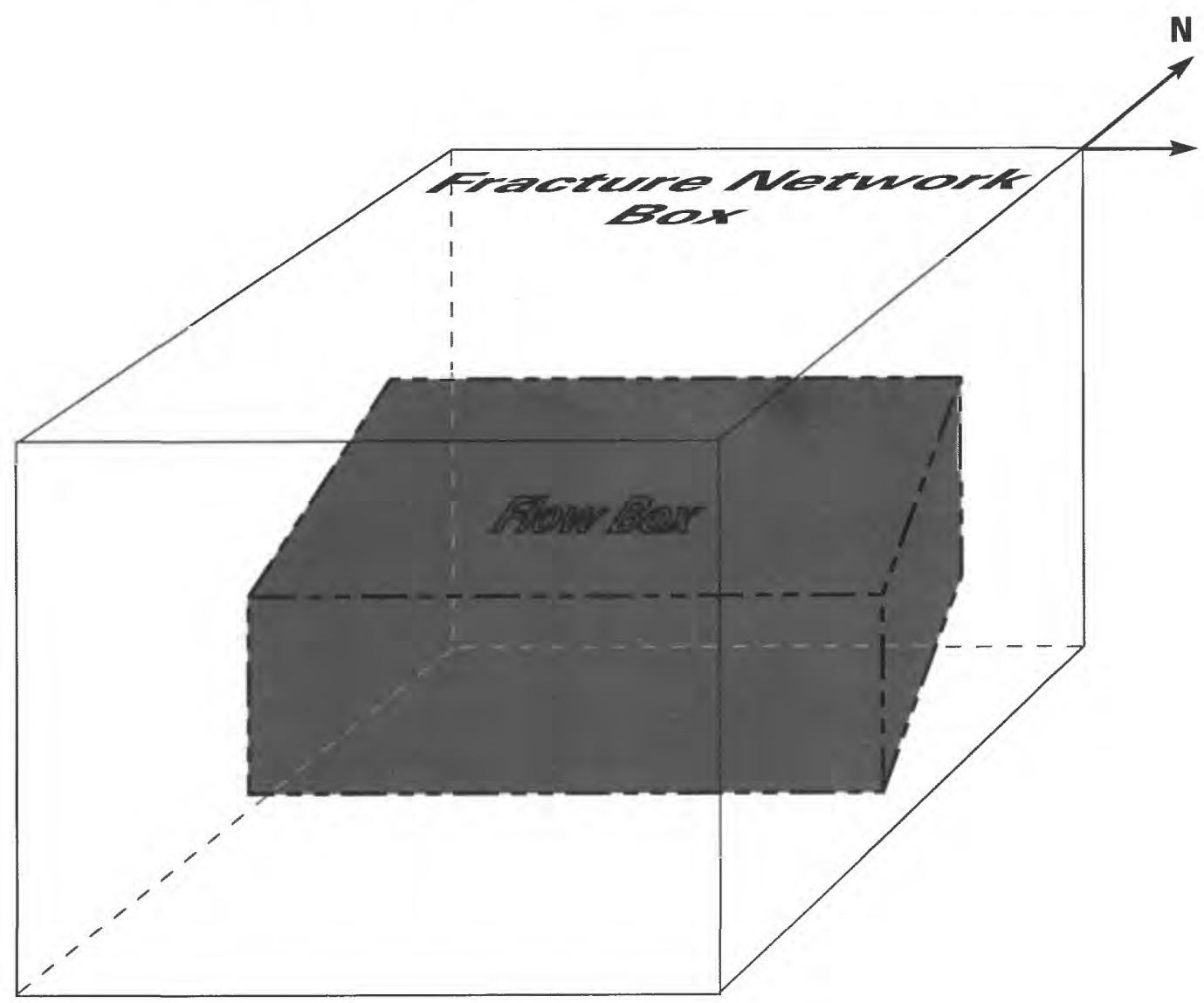

Figure 12. Network and flow box configuration to determine directional permeability parallel to gradient. 
Table 15. Bulk saturated directional permeabilities for 200meter $\times 200$-meter $\times 60$-meter flow box, Tiva Canyon Tuff

[Based on 10 realizations, steady state simulations; $\mathrm{m}^{2}$, square meters]

\begin{tabular}{lcc}
\hline $\begin{array}{c}\text { Constant head } \\
\text { gradient from }\end{array}$ & \multicolumn{2}{c}{$\begin{array}{c}\text { Bulk saturated permeability } \\
\left(\mathrm{m}^{2}, \text { no matrix }\right)\end{array}$} \\
\cline { 2 - 3 } Top to bottom & Mean & Standard deviation \\
East to west & $5.371 \times 10^{-12}$ & $6.433 \times 10^{-13}$ \\
South to north & $1.268 \times 10^{-12}$ & $2.689 \times 10^{-13}$ \\
SE to NW & $2.358 \times 10^{-12}$ & $2.593 \times 10^{-13}$ \\
SW to NE & $1.262 \times 10^{-12}$ & $1.780 \times 10^{-13}$ \\
Geometric mean & $1.304 \times 10^{-12}$ & $2.434 \times 10^{-13}$ \\
\hline
\end{tabular}

The effect of scale on directional permeability can be analyzed by increasing the size of the network and flow region. The permeability for individual and combined directions can be calculated for each scale and compared. As described above, two different scale network and flow regions were generated. The flow box was slightly smaller than the network slab to avoid edge effects and so the domain would fit inside the slab even when rotated.

Mean directional permeabilities for the $150-\mathrm{m} \times$ $150-\mathrm{m} \times 60-\mathrm{m}$ flow box vary by almost two orders of magnitude ranging from $2.657 \times 10^{-13} \mathrm{~m}^{2}$ (top to bottom) to $2.805 \times 10^{-11} \mathrm{~m}^{2}$ (east to west). Results also show the east-west direction was the most conductive (as related to permeability, not path conductance), while the top-bottom direction was the least conductive. This implies that the principal permeability direction is easterly. In addition, the permeability values indicate that the volume is anisotropic.

Mean directional permeabilities for the $200-\mathrm{m} \times$ $200-\mathrm{m} \times 60$-m flow box vary by only a factor of four ranging from $1.262 \times 10^{-12} \mathrm{~m}^{2}$ (southeast to northwest) to $5.371 \times 10^{-12} \mathrm{~m}^{2}$ (top to bottom). Results also show the top-bottom direction is the most conductive, while the southwest-northeast, southeast-northwest, and the east-west directions were about equally nonconductive. This implies that the principal permeability direction is vertical. In addition, the permeability values indicate the volume is also anisotropic, but less so than for the 150-m scale block analysis.

When comparing the ranges of permeabilities of the two flow domains, the extremes come from top to bottom and east to west. In the $150-\mathrm{m}$ scale the minimum and maximum permeability is from top to bottom and from east to west, respectively. For the $200-\mathrm{m}$ scale the reverse is true. Minimum permeability is from east to west, southeast to northwest, and southwest to northeast, and maximum is from top to bottom (fig. 13). In both flow scales, top to bottom has a single fracture pathway and also the lowest conductivity and fracture area of any of the flow directions. Even though there is some permeability variability among the ten realizations in the 150-m flow scale (fig. 13), there does not appear to be enough variability to explain the reverse in permeability from top to bottom from the $200-\mathrm{m}$ flow scale. In any case, there is no clear explanation for the pattern of directional permeability compared with pathway conductivity and fracture area.

Perhaps the orientation of the fractures in the two flow domains that are part of the pathway are orientated differently relative to the direction of gradient. More than 10 realizations may be needed to increase the range of possible outcomes. It is clear that more than two scales need to be simulated to establish a clearer relation of permeability to block scale. The same phenomenon of one fracture pathway from top to bottom would probably occur for any block size with a thickness of $60 \mathrm{~m}$ or less. The large fractures at the tail end of the distribution curve will dominate the vertical geometry. As the thickness approaches and exceeds the maximum simulated fracture length of $100 \mathrm{~m}$, any top to bottom connecting pathway will have to include more than one fracture. 
a.

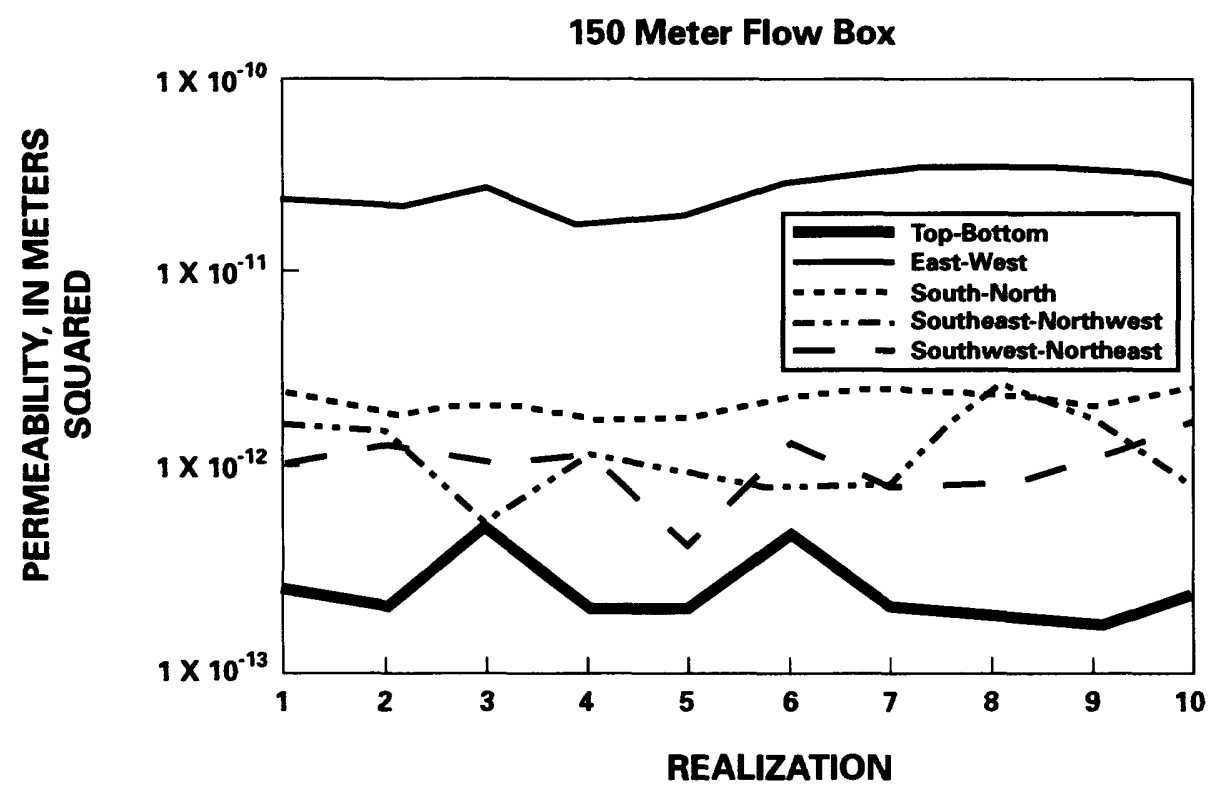

b.

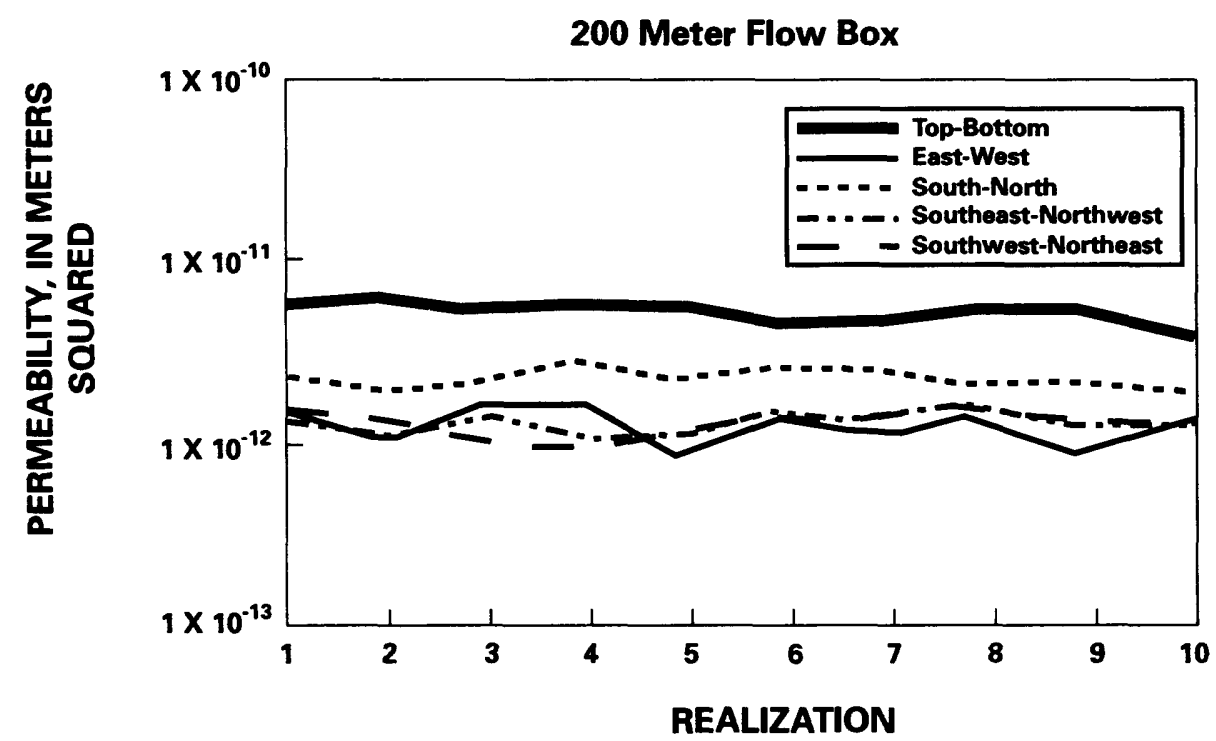

Figure 13. Permeability distribution for 10 realizations. a.) $150 \mathrm{~m}$ flow box; b.) $200 \mathrm{~m}$ flow box. 


\section{CONCLUSIONS}

This report is part of a preliminary modeling effort to investigate the effects of fractures on flow and transport of water and gas at Yucca Mountain. A threedimensional fracture network of the ESF starter tunnel area was calibrated to field data. The simulated network reasonably replicates the real fracture network because simulated intensities match well with mapped intensities. The fracture network was simulated by eliminating nonconductive fractures determined from field-derived air permeabilities. The analysis shows that the connected fracture system in the ESF starter tunnel area has numerous networks (fractures connected to each other) and has a high permeability distribution with a large standard deviation. However, pathway analysis shows that although there are numerous networks, there are few connections between them, as shown in the the three radial boreholes in alcove \#1, which is consistent with cross-borehole pressure testing.

Based on the results of the starter tunnel simulation, two volumes representing three-dimensional fracture networks of the Tiva Canyon Tuff were also simulated. One network was $150 \times 150 \times 60 \mathrm{~m}$ and the other was $200 \times 200 \times 60 \mathrm{~m}$. Pathway analysis showed that at these scales, there was only one pathway from one end of the network to the opposite end. The usual pathway was along one large fracture from top to bottom of the block, whereas, in other directions, the pathway was composed of multiple connected fractures.

Small fractures could be truncated from the simulated network in the Tiva Canyon Tuff without any effect on the overall connectivity. Fractures as long as $1.25 \mathrm{~m}$ were eliminated from the network without altering the number of pathways. This result indicates that fracture length is one of the more important factors in determining network connectivity.

Directional permeabilities of the $150-\mathrm{m}$ scale flow domain of the Tiva Canyon Tuff vary by almost two orders of magnitude with the east-west direction as the most conductive, and the top-bottom direction as the least conductive. This implies that the principal permeability direction is easterly. Directional permeabilities of the $200-\mathrm{m}$ scale flow box varies by only a factor of four, with the top-bottom direction as the most conductive, while the southwest-northeast, southeastnorthwest, and the east-west directions were about equally nonconductive. This implies that the principal permeability direction is vertical. Both volumes, how- ever, behave anisotropically with the larger volume showing the least amount of variation in all directions.

\section{REFERENCES}

Andersson, J., and Dverstorp, B., 1987, Conditional simulation of fluid flow in three-dimensional networks of discrete fractures: Water Resources Research, v. 23, no. 10, p. $1,876-1,886$.

Anderson, L.A., 1984, Rock property measurements on large volume core samples from Yucca Mountain, USW GU3/G3 and G-4 boreholes, Nevada Test Site, Nevada: U.S. Geological Survey Open-File Report 84-552, 39 p.

Anderson, L.A., 1991, Results of rock property measurements made on core samples from Yucca Mountain, Nevada Test Site, Nevada: U.S. Geological Survey Open File-Report 90-474, 43 p.

Barton. C.C., and Larsen. E., 1986, Pattern of development of fracture networks (abs.): Geological Society of America Abstracts with Programs, v. 18, no. 6, p. 536.

Barton, C.C., Larsen, E., Page, W. R., and Howard, T.M., 1993, Characterizing fractured rock for fluid flow, geomechanical , and paleostress modeling: Methods and preliminary results from Yucca Mountain, Nevada: U.S. Geological Survey Open-File Report 93-269, 62 p.

Barton, C.C., and La Pointe, P.R., 1995, Creating reservoir simulations with fractal characteristics, in Barton C.C., and La Pointe, P.R., eds, Fractals in Petroleum Geology and Earth Processes, New York, Plenum Press, 263-276 p.

Baecher, G.B., Lanney, N.A., and Einstein, H.H., 1977 , Statistical descriptions of rock properties and sampling: Proceedings 18th U.S. Symposium on Rock Mechanics, Topical Mechanics, American Institute Mining Engineers.

Buesch, D.C., Spengler, R.W., Moyer, T.C., and Geslin, J.K., 1996, Revised stratigraphic nomenclature and macroscopic identification of lithostratigraphic units of the Paintbrush Group exposed at Yucca Mountain, Nevada: U.S. Geological Survey Open File Report 94-469, 45 p.

Cacas, M. C., Ledoux, E., de Marsily, G., and Tillie, B., 1990, Modeling fracture flow with a stochastic discrete fracture network, calibration and validation, 1. the flow model: Water Resources Research, v. 26, no. 3, p. 479-489.

Carr, W. J., 1984, Regional structural setting of Yucca Mountain southwestern Nevada, and Late Cenozoic rates of tectonic activity in part of the southwestern Great Basin, Nevada and California: U.S. Geological Survey Open-File Report 84-854, 109 p.

Dershowitz, W., Lee, G., Geier, J., Hitchcock, S., and La Pointe, P., 1994, FracMan version 2.4 -Interactive discrete feature data analysis, geometric modeling and exploration simulation: User Documentation, Redmond, Wash., Golder Associates, Inc., 171 p. 
Dershowitz, W.P., Wallmann, P., and Kindred, S., 1991, Discrete fracture modeling for the Stripa Site Characterization and validation drift inflow predictions: Stockholm, Sweden, SKB [Svensk Kavnbranslehantering AB] Stripa Project Technical Report 91-16, 45 p.

Efron, B., 1982, The jackknife, the bootstrap, and other resampling plans: SIAM Monograph no. 38, Society of Industrial and Applied Mathematics.

Fisher, R.A., 1953, Dispersion on a sphere: Proceedings of the Royal Society of London, series A, 217, p. 295-306.

Frizzell, V.A., and Shulters, J., 1990, Geologic map of the Nevada test site, southern Nevada: U.S. Geological Survey Miscellaneous Investigations Series Map I-2046.

Geslin, J.K., Moyer, T.C., Flint, L.E., 1995, Stratigraphic relations and hydrologic properties of the Paintbrush Tuff nonwelded (PTn) hydrologic unit, Yucca Mountain, Nevada: U.S. Geological Survey Open-File Report 95-397, $151 \mathrm{p}$.

Hudson, J.A., and Priest, S.D., 1983, Discontinuities and rock mass geometry [abs]: International Journal Rock Mechanics, Mineral Science and Geomechanics, v. 20, no. 2, p. 73-89.

Istok, J.D., Rautman, C.A., Flint, L.E., and Flint, A.L., 1994, Spatial variability in hydrologic properties of a volcanic tuff: Ground Water, v. 32, no. 5, p. 751-760.

King, P.B., 1975, Ancient southern margin of North America: Geology, v. 3, no. 12, p. 732-734.

1985, Characterization and interpretation of rock mass joint patterns: Geological Society America Special Paper 199, 37 p.

La Pointe, P.R., Wallmann, P., and Follin, S., 1995, Estimation of effective block conductivities based on discrete network analyses using data from the Aspo site: Stockholm, Sweden, SKB [Svensk karnbranslehantesing AB] Stripa Technical Report 95-15, 141 p.

LeCain, G.D., 1995, Pneumatic testing in 45-degree inclined boreholes in ash flow tuff near Superior, Arizona: U.S. Geological Survey Water-Resources Investigations Report 95-4073, 27 p.

LeCain, G.D., 1997, Air-injected testing in vertical boreholes in welded and nonwelded tuff, Yucca Mountain, Nevada: U.S. Geological Survey Water-Resources Investigations Report 96-4262, 33 p.

Long, J.C.S., Remer, J.S., Wilson, C.R. , and Witherspoon, P.A. 1982, Porous media equivalents for networks of discontinuous fractures: Water Resources Research, v. 18 , no. 3, p. 645-658.

Miller, I. Lee, G., Dershowitz, W., and Sharp, G., 1994, Matrix/fracture interaction code with solute transport: MAFIC User Documentation, version ·1.4, Redmond, Wash, Golder Associates Inc., 58 p.

Montazer, P., and Wilson, W. E., 1984, Conceptual hydrologic model of flow in the unsaturated zone, Yucca Mountain, Nevada: U.S. Geological Survey Water Resources Investigations Report, 84-4345, 55 p.
Nelson, P.H., and Anderson, L.A., 1992, Physical properties of ash flow tuffs from Yucca Mountain, Nevada: Journal Geophysical Research, v. 97, no. B5, p. 6,823-6,841.

O'Neil, J.M., Whitney, J.W., Hudson, M.R., 1992, Photogeologic and kinematic analysis of lineaments at Yucca Mountain, Nevada: Implications for strike-slip faulting and oroclinal bending: U.S. Geological Survey Open-File Report 91-623, 24 p.

Odling, N. E., 1995, The development of network properties in natural fracture patterns, in Myer, L.R., Tsang, C.F., Cook, N.G., and Goodman, R.E., eds., Fractured and Jointed Rock Masses,. Proceedings of the conference on fractured and jointed rock masses, Lake Tahoe, Calif., June 3, 1992, Brookfield, A.A. Balkema, p. $35-41$.

Odling, N.E., and Webman, I., 1990, A conductance mesh approach to the permeability of natural and simulated fracture patterns, Water Resources Research, v. 27, pp. 2,633-2,643.

Ortiz, T.S., Williams, R.L., Nimick, F.B., Whittet, B.C., and South, D.L., 1985, A three-dimensional model of reference thermal/mechanical and hydrological stratigraphy at Yucca Mountain, southern Nevada: Sandia Report SAND84-1076, Sandia National Laboratories, Albuquerque, N. Mex., 76 p.

Osnes, J.D., Winberg, A., and Anderson, J., 1988, Analysis of well test data - application of probabilistic models to infer hydraulic properties of fractures: Rapid City, South Dakota Topical Report RSI-0338, RE/SPEC Inc.

Rautman, C.A., and Flint, A.L., 1992, Deterministic geologic processes and stochastic modeling: Albuquerque, N.M., Sandia National Laboratories, SAND91-1925C.

Riehle, J.R., 1973, Calculated compaction profiles of rhyolitic ash flow tuffs: Boulder, Colo., Geological Society of America Bulletin, v. 84, p. 2,193-2,216.

Riehle, J.R., Miller, T.F., and Bailey, R.A., 1995, Cooling, degassing, and compaction of rhyolitic ash flow tuffs: A computational model: Volcanology Bulletin, v. 57, p. 319-336.

Schlumberger, 1972, Log interpretation volume 1-Principles: New York, Schlumberger Ltd., 113 p.

Scott, R.B. 1990, Tectonic setting of Yucca Mountain, southwest Nevada, in Wernicke, B.P., ed., Basin and Range extensional tectonics near the latitude of Las Vegas, Nevada: Boulder, Colo., Geological Society of America Memoir 176, p. 251-282.

Scott, R.B. and Bonk, J., 1984, Preliminary geologic map of Yucca Mountain, Nye County, Nevada with geologic sections: U.S. Geological Survey Open-File Report 84-494, 2 sheets, 1: 12,000.

Scott, R.B., and Castellanos, M., 1984, Stratigraphic and structural relations of volcanic rock in drill holes USW GU-3 and USW G-3, Yucca Mountain, Nye County, Nevada: U.S. Geological Survey Open-File Report 84-491, 121 p. 
Snyder, D.B., and Carr, W.J., 1984, Interpretation of gravity data in a complex volcanic-tectonic setting, southwestern, Nevada: Journal of Geophysical Research, v. 89, no. B12, p. 10,193-10,206.

Spengler, R.W., and Chornack, M., 1984, Stratigraphic and structural characteristics of volcanic rocks in core hole USW G-4, Yucca Mountain, Nye County, Nevada: U.S. Geological Survey Open-File Report 84-789, $77 \mathrm{p}$.

Spengler, R.W., and Fox, K.F., 1989, Stratigraphic and structural framework of Yucca Mountain, Nevada: Radioactive Waste Management and the Nuclear Fuel Cycle, v. 13 , no. $1-4$, p. $21-36$.

Terzaghi, R., 1965, Sources of error in joint surveys: Geotechnique, v. 15, p. 287-303.

Throckmorton, C.K., and Verbeek, E.R., 1995, Joint networks in the Tiva Canyon and Topopah Spring Tuffs of the Paintbrush Group, southwestern Nevada:

U.S. Geological Survey Open-File Report 95-2, 179 p.
Warren, J.E., and Root, P.J., 1963, The behavior of naturally fractured reservoirs: Society of Petroleum Engineers Journal, AIME, September, p. 243-255.

Whitfield, M.S., Cope, C.M., and Loskot, C.L., 1993, Borehole and geohydrological data for test hole USW UZ-6, Yucca Mountain area, Nye County, Nevada: U.S. Geological Survey Open-File Report 92-28, 36 p.

Witherspoon, P.A., Wang, J.S.Y., Iwal, K., and Gale, J.E., 1980 , Validity of cubic law for fluid flow in a deformable rock fracture: Water Resources Research, v. 16, no. 6, p. 1,016-1,024.

Wittwer, C.S., Chen, G., Bodvarsson, G.S., 1993, Studies of the role of fault zones on fluid flow using the site-scale numerical model of Yucca Mountain: La Grange Park, III., American Nuclear Society, Proceedings of the 4th Annual International Conference, April, 1993, High Level Radioactive Waste Management, Las Vegas, Nevada, American Nuclear Society, p. 667-674.

Wright, L.A., 1976, Late Cenozoic fault patterns and stress fields, in the Great Basin and westward displacement of the Sierra Nevada block: Geology, v. 4, p. 489-494. 